\title{
'Exxon Valdez' oil spill: impacts and recovery in the soft-bottom benthic community in and adjacent to eelgrass beds
}

\author{
Stephen C. Jewett ${ }^{1, *}$, Thomas A. Dean ${ }^{2}$, Richard O. Smith ${ }^{2}$, Arny Blanchard ${ }^{1}$ \\ ${ }^{1}$ Institute of Marine Science, School oi Fisheries and Ocean Sciences, University of Alaska Fairbanks, \\ Fairbanks, Alaska 99775, USA \\ ${ }^{2}$ Coastal Resources Associates, Inc., 1185 Park Center Drive, Suite A, Vista, California 92083, USA
}

\begin{abstract}
We assessed impacts of the 'Exxon Valdez' oil spill on benthic communities within and adjacent to eelgrass beds in Prince William Sound, Alaska, USA. The concentration of total polynuclear aromatic hydrocarbons (TPA.Hs), benthic community composition, diversity, biomass, and abundance were compared between matched pairs of oiled and reference sites in 1990 (approx. 16 mo after the spill), and in 1991, 1993, and 1995. TPAHs in sediments were high (up to $15300 \mathrm{ng} \mathrm{g}^{-1}$ ) at sites adjacent to oiled shorelines in 1990, but declined sharply thereafter. Some reference sites in 1990-91 also had elevated TPAHs in sediments and signatures matching Exxon Valdez oil, but concentrations were significantly lower than at oiled sites. Based on classification and ordination analyses, communities of infauna and small epifauna at some oiled sites in 1990 differed from communities at reference sites, and from the same sites in subsequent years. Percent sand and mud and concentration of total chrysenes (PAH analytes indicative of crude oil) explained significant proportions of the temporal and spatial variation in benthic community structure. Total abundance and biomass of epifauna were generally higher at oiled sites, primarily because of higher densities of epifaunal bivalves. Otherwise, there were few consistent community-wide responses to oiling in diversity, richness, total abundance, total biomass, or the abundances of major taxonomic groups (e.g. polychaetes or bivalves). We attribute the lack of a stronger community-wide response to the varying sensitivities of constituent taxa to oil and organic enrichment. Over half of the dominant families differed with respect to abundance at oiled versus reference sites. Most, including 9 families of polychaetes, were more abundant at oiled sites. Most of these were stress-tolerant or opportunistic, and their increase was likely due to organic enrichment. Negative impacts were most evident in oil-sensitive amphipods, especially the families Isaeidae and Phoxocephalidae. There were consistently more of these amphipods at reference sites, and abundances at oiled sites were likely reduced as a result of oil toxicity. Most of these differences between oiled and reference sites persisted through 1995, 6 yr after the spill. We suspect that these differences are a result of the spill, but we rely on post-spill comparisons to infer impacts, and our conclusions rely on the untestable assumption of equality between oiled and reference sites in the absence of a spill. Future assessments of the impacts of oil spills or other accidental environmental disturbances could benefit from pre-impact studies that provlde objective criteria for selection of matched pairs of sites, thereby supporting the assumption of equality in the absence of the disturbance.
\end{abstract}

KEY WORDS: 'Exxon Valdez' - Oil spill · Subtidal · Eelgrass · Benthos · Infauna · Prince William Sound · Alaska

\section{INTRODUCTION}

Oil spills are major sources of localized disturbance in the marine environment and can have severe impacts on nearshore biota (NRC 1985). Our knowl-

·E-mail: jewett@ims.uaf.edu edge of oil impacts stems primarily from 2 sources: (1) laboratory studies of the toxicity of individual species in isolation; and (2) opportunistic field assessments that examine the impacts of accidental spills. The former provide detailed physiological and toxicological information about the impacts of oil, but are of limited value in predicting impacts of a given spill on biological communities. This is because (1) spills vary with 
respect to the types and amount of oil released, (2) physical conditions cause variation in the dispersal and weathering of oil, (3) the toxicity of spilled oil varies based on the type spilled and how it is weathered, (4) sensitivities of animals vary among species and not all species have toxicity test data so substitutions are made, and (5) systems are complex and impacts often result from indirect effects (e.g. reduction in predator abundance) or cleanup efforts rather than direct toxicological impacts. There are some data from controlled experimental spills (Cross et al. 1987) and mesocosm studies (Grassle et al. 1981, Elmgren \& Frithsen 1982), but these are few. As a result, our most reliable understanding of how spills impact the environment and affect natural biota comes from examination of impacts from accidental spills.

Accidental spills in marine coastal environments often result in the coating of the shoreline with oil, and can lead to immediate and readily detectable impacts to the biota (NRC 1985), but impacts are less obvious to nearshore subtidal habitats because these are out of sight. Oil often finds its way into the subtidal via diffusion, or more importantly from settlement of oiled particulates often derived from beached oil that is redistributed by waves and cleanup activities (Boehm et al. 1987, Owens et al. 1987, Short et al. 1996a). The oil can be absorbed onto inorganic particles (Meyers \& Quinn 1973), or ingested by zooplankton and incorporated into feces that settle onto subtidal sediments (Conover 1971, Bassin \& Ichiye 1977, Clark \& MacLeod 1977). Nearshore subtidal zones, and especially soft-sediment environments in protected bays, often serve as reservoirs of oil that can persist for long periods of time (Gundlach et al. 1983, NRC 1985, Page et al. 1995). Impacts to epifaunal and infaunal organisms can be severe but are often unpredictable. The same spill can lead to enhancement of some species via organic enrichment, and to the local extinction of more sensitive species as the result of toxicity. This dual response (toxicity and organic enrichment) to pollution is inherant in most studies on environmental effects of hydrocarbon exposure (e.g. Spies \& DesMarais 1983, Olsgard \& Gray 1995, Peterson et al. 1996). In 3 of the most well studied coastal spills, the 'Florida' spill off the coast of West Falmouth, Massachusetts, USA (Sanders et al. 1980), the 'Amoco Cadiz' spill off the Brittany coast of France (Jacobs 1980, Glémarec \& Hussenot 1982, Ibanez \& Dauvin 1988), and the 'Tsesis' oil spill off the Swedish Baltic coast (Kineman et al. 1980, Elmgren et al. 1983), there were extreme increases as well as decreases in benthic infauna at heavily oiled sites. Impacts varied among spills and among species within a spill, but in all cases, there was a reduction in 1 or more amphipod species and an increase in opportunistic polychaete species. In the longest studied oil spill, the 'Amoco Cadiz', the benthic community moved through several successive periods of temporal change (Jacobs 1980, Dauvin 1982, Glémarec \& Hussenot 1982, Ibanez \& Dauvin 1988, Warwick \& Clarke 1993) until the community approached a stable 'climax' environment nearly 20 yr after the spill (Dauvin 1998).

In March 1989, the super tanker 'Exxon Valdez' ran aground on Bligh Reef in Prince William Sound, Alaska, and spilled nearly 42 million l of crude oil, the largest spill in U.S. history (Spies et al. 1996). The oil was driven by wind and currents, and much of it found its way into sheltered embayments within the Sound (Kelso \& Kendziorek 1991, Maki 1991). About half of the oil became stranded on the shoreline, and an estimated $13 \%$ was deposited in subtidal sediments (as of fall 1992; Wolfe et al. 1994). These shorelines were subsequently subjected to extensive and intensive cleanup activities (reviewed in Mearns 1996). Shortly after the spill, plants and animals living on or in shallow subtidal sediments were directly exposed to beached oil and oil-contaminated fine sediments that were reintroduced into nearshore waters by waveinduced redistribution, leaching by groundwater flowing through the intertidal region, and flushing seaward by shoreline cleanup activities (Boehm et al. 1987. O'Clair et al. 1996. Short et al. 1996a). Most of this reintroduced oil, oil absorbed onto inorganic particles and oil incorporated into feces, subsequently settled subtidally at depths less than 20 m (Carlson \& Kvenvolden 1996, O'Clair et al. 1996).

There was extensive injury to nearshore environments as a joint result of the 'Exxon Valdez' spill and associated cleanup efforts. These included reductions in the abundance and cover by the dominant intertidal alga Fucus gardneri and reductions to a suite of intertidal infauna and epifauna (e.g. De Vogelaere \& Foster 1994, Gilfillan et al. 1995, Driskell et al. 1996, Highsmith et al. 1996, Houghton et al. 1996, Stekoll et al. 1996, van Tamelen et al. 1997). Assemblages of infauna from oiled mixed-soft beaches and epifauna from oiled sheltered rocky shores were essentially recovered by the summer of 1991; sites subjected to high-pressure hot-water washing remained in early stages of recovery for both infauna and epifauna by the summer 1992 (Driskell et al. 1996, Houghton et al. 1996). Injuries appeared to be less severe in subtidal habitats. There were possible impacts to subtidal algae based upon higher densities of at least 1 of the dominant kelps (Agarum clathratum, Laminaria saccharina, Nereocystis luetkeana) at oiled sites, and generally more smaller plants there (Dean et al. 1996a). Eelgrass Zostera marina populations showed reductions in flowering and shoot density and recovered within 2 yr after the spill (Dean et al. 1998). There were catastrophic declines in benthic infauna in a heavily oiled fjord sev- 
eral months after the spill that was associated with anoxic conditions (Jewrett et al. 1996). The presence of oil may have exacerbated the local deletion of oxygen, but anoxia can occur naturally in these environments, and it is uncertain whether the spill contributed to this condition. There was a reduction in several large epifauna found in subtidal kelp and eelgrass beds, including the leather sea star Dermasterias imbricata and the helmet crab Telmessus cheiragonus (Dean et al. 1996b) at depths $<20 \mathrm{~m}$, but there were no detectable injuries to Tanner crab Chionoecetes bairdi and pandalid shrimp Pandalus spp. at depths of 20 to $150 \mathrm{~m}$ (Armstrong et al. 1995). Also, Feder \& Blanchard (1998) analyzed infauna from 14 bays in the Sound in 1990 at 40 , 100 , and $>100 \mathrm{~m}$, and found no detectable effects on the biota 16 mo after the spill. The spill also resulted in the reduction in the numbers of several important predators in the nearshore zone, including sea otters Enhydra lutra (Ballachey et al. 1994), that can have a profound influence on the structure of nearshore communities (Estes \& Duggins 1995) including those on soft bottoms (Kvitek \& Oliver 1992a, b).

In this study, we examined the effect of the 'Exxon Valdez' oil spill on the nearshore benthic community in eelgrass beds and immediately offshore of the beds, and followed the recovery of the community for a period of 6 yr after the spill. The shallow subtidal zone less than $20 \mathrm{~m}$ deep in Prince William Sound typically has dense stands of kelps (on rocky shores) or eelgrass (in soft sediment). Eelgrass beds generally occur at stream mouths in protected bays and extend from the lower intertidal (about $0.5 \mathrm{~m}$ mean lower low water, MLLW) to depths of about $5 \mathrm{~m}$ (McRoy 1970, Dean et al. 1998). Soft substrata outside of the eelgrass beds consist mainly of mud and sand that is largely devoid of macrophytes except for the occasional Laminaria saccharina (S. Jewett \& T. Dean pers. obs.). Eelgrass communities are among the most productive habitats in Alaska (McRoy 1970, Phillips 1984) and elsewhere (e.g. Boström \& Bonsdorff 1997), and they serve as important nursery and feeding grounds for a variety of invertebrates, fish, birds, and marine mammals (Thayer \& Phillips 1977, McConnaughey \& McRoy 1979, Feder \& Jewett 1987).

\section{METHODS}

Sampling. The impacts to the benthos were assessed using a stratified random sampling design. Community parameters (abundance, biomass, diversity, and richness) of epibenthic and infaunal invertebrates, as well as densities of all numerically dominant invertebrate families, were measured at matched pairs of oiled and unoiled reference sites beginning 13 mo after the spill as described in Dean et al. (1996a, b, 1998). There were no pre-spill data, and out of necessity we relied on a comparison of oiled and reference sites sampled after the spill to evaluate impacts rather than a more ideal BACl (Before-After, Control-Impact) design (Wiens \& Parker 1995, Stewart-Oaten 1996). Oiled areas were identified based on the summer 1989 oil survey maps and the September 1989 shoreline surveys (ADEC 1989). Briefly, eelgrass beds adjacent to moderately to heavily oiled shorelines were stratified by geographic region, and 1 site from each region was randomly selected. Reference sites were chosen that matched the oiled sites as closely as possible with respect to aspect, proximity to fresh-water run-off, slope, wave exposure, and water circulation. Sampling was conducted in July or August at 4 pairs of sites in 1990, 5 in 1991, 3 in 1993, and 4 in 1995. Data from only those 3 pairs of sites sampled in each year are presented here. The oiled/reference site pairs were Bay of Isles/Drier Bay, Herring Bay/Lower Herring Bay, and Sleepy Bay/Moose Lips Bay, respectively (Fig. 1).

Two depth strata were sampled adjacent to each $200 \mathrm{~m}$ section of shoreline selected for sampling: 6 to $20 \mathrm{~m}$ and within the eelgrass bed (generally $<3 \mathrm{~m}$ ). Within each stratum, three $30 \mathrm{~m}$ sampling transects, run parallel to shore, were placed at randomly selected locations. Transects within the eelgrass bed were placed in what was perceived as the center of the depth distribution of eelgrass. The sites in the deeper stratum were placed at randomly selected depths. Random positions along the shore and random depths were reassigned prior to each year.

Densities of infaunal invertebrates were estimated from two $0.1 \mathrm{~m}^{2}$ by $10 \mathrm{~cm}$ deep diver-collected suction dredge samples taken from each of the 3 sampling transects within each depth stratum. The 2 dredge samples were spaced $7.5 \mathrm{~m}$ apart, with the initial sampling position at a random distance along the sampling transect. In the eelgrass bed, eelgrass shoots were cut off just above the sediments' surface, removed, and counted prior to taking suction dredge samples. The dredge sampler was fitted with a collection bag with a mesh size of $1 \mathrm{~mm}$.

Divers also collected 2 sediment samples from each transect and depth stratum. Surface sediments were collected from within $3 \mathrm{~m}$ of the start of each sampling transect. The samples were collected to depths $<5 \mathrm{~cm}$ in pre-cleaned wide mouth jars and frozen immediately after collection. One of the samples was used to determine sediment grain-size composition and the other to determine hydrocarbon concentrations.

Laboratory analyses. Benthic samples were returned to the laboratory where they were sieved through a $1 \mathrm{~mm}$ mesh, and the animals were identified, counted, and weighed (blotted-wet wt). Organisms 


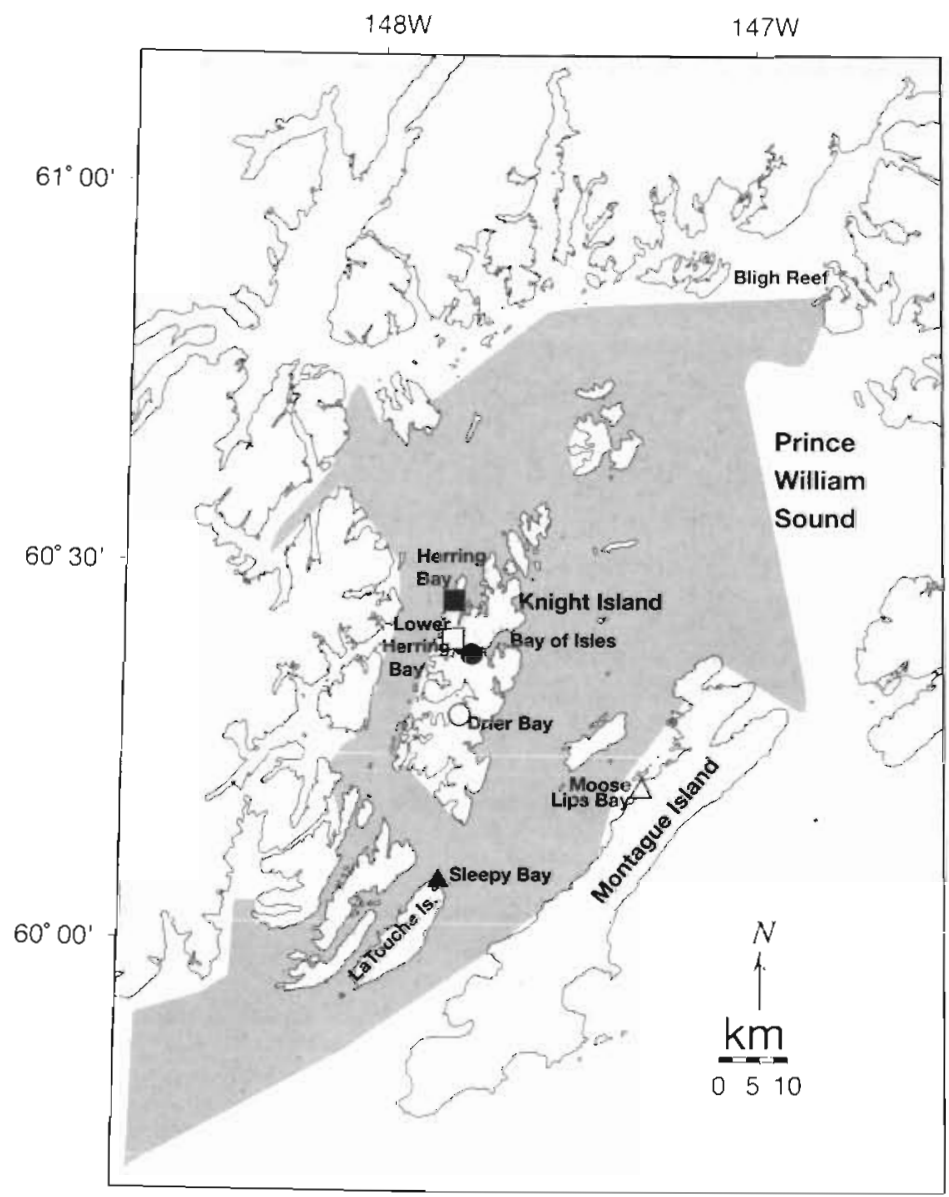

Fig. 1. Eelgrass sampling sites in Prince William Sound. Three oiled (ロ, $\Delta) /$ reference $(\square, O, \Delta$ ) site pairs are shown. Also depicted is the site of the 'Exxon Valdez' grounding on Bligh Reef and the trajectory of the spill

were generally identified to at least the family level, but there were a few instances when only higher taxonomic levels were assigned to an individual. Many of the more common organisms were identified to species. Meiofauna $(\leq 0.5 \mathrm{~mm})$ and highly motile, non-benthic forms, such as mysids and fishes were excluded from the analyses.

Sediment granulometric analysis was conducted using the pipette-sieve method, providing conventional grain-size parameters (Folk 1980). Hydrocarbon analyses were performed by the Geochemical and Environmental Research Group at Texas A\&M University (in 1990 and 1991) and the Technical Services Task Force, Analytical Chemistry Group (TSTF-ACG), NOAA/NMFS, Auke Bay, Alaska (in 1993 and 1995). Hydrocarbons were extracted from the sediment samples and analyzed for the concentration of various hydrocarbon fractions using gas chromatography combined with a mass spectrometer detector (Short et al. 1996b). All hydrocarbon data are reported on a dry weight basis (ng $g^{-1}$ ).
Chemical analysis of sediments yielded values for several component hydrocarbon analytes. We report the concentrations of total polynuclear aromatic hydrocarbon (TPAH) fractions minus perylene and sum of the chrysenes as indicators of the contribution of 'Exxon Valdez' oil. Perylene was excluded because it is a naturally occurring PAH compound that is produced diagenetically in marine sediments (Venkatesan 1988) and is not petroleum-derived. While concentrations of TPAH reflect the distribution of petroleum-derived hydrocarbons, a portion of the TPAHs observed may have been derived from petroleum hydrocarbons other than 'Exxon Valdez' oil, especially diesel fuel. Chrysene concentrations were used as more specific indicators of 'Exxon Valdez' oil, because chrysenes are present in crude oil (including 'Exxon Valdez' oil) but not in diesel fuel (Bence \& Burns 1995). Both TPAH and chrysene values may include some PAHs from non-anthropogenic sources and from sources other than 'Exxon Valdez' oil (e.g. fuel spilled from cleanup and research vessels), and thus, do not necessarily represent absolute concentrations attributable to the oil spill. However, there is no reason to suspect biases with respect to the distribution of non-spill related oil at oiled versus reference sites. Therefore, differences in concentrations of TPAHs and chrysenes at oiled versus reference sites should reflect relative impacts of the spill.

Results of the chemical analysis were screened on the basis of surrogate recoveries and minimum detection limits (MDLs). Individual analytes and the summary statistics affected by them were excluded from the analysis if the recoveries of corresponding analyte surrogates fell outside the range 30 to $150 \%$. For example, if the surrogate of $1 \mathrm{PAH}$ analyte fell outside the acceptable range, the TPAH concentration for that sample was excluded from the analysis. Dry weight concentrations of individual analytes reported below MDL were replaced by '0s' for our analyses. The MDL for aromatic hydrocarbons was $1 \mathrm{ng}^{-1}$.

Criteria were established for comparing hydrocarbon concentrations in sediments with those in 'Exxon Valdez' oil (J. Short, NOAA/NMFS, pers comm.). The pattern of PAH concentrations in the sediment samples was judged similar to 'Exxon Valdez' oil if it met 3 criteria: (1) the ratio of alkyl dibenzothiophenes (summed) to alkyl phenanthrenes (summed) exceeded $0.3 ;(2)$ the ratio of alkyl chrysenes (summed) to alkyl phenanthrenes (summed) exceeded 0.05; and (3) the concentration of alkyl phenanthrenes exceeded $25 \mathrm{ng} \mathrm{g}^{-1}$. This test is similar to, but more conservative than, the method used by O'Clair et al. (1996). 
Data analyses. The data were analyzed using both multivariate and univariate techniques. Multivariate analyses were used to examine spatial and temporal patterns in community composition, and to test for the correspondence of these patterns with changes in environmental variables. The Bray-Curtis dissimilarity coefficient (Bray \& Curtis 1957) was calculated using $\ln (x+1)$-transformed family-level abundance data (ind. $0.1 \mathrm{~m}^{-2}$ ) for dissimilarity matrices. Separate matrices were produced for each depth stratum and for infauna and epifauna. Agglomerative unweighted group-averaging cluster analyses (Clifford \& Stephenson 1975) and nonmetric multidimensional scaling (MDS; Field et al. 1982) were applied to the dissimilarity matrices to provide the initial classification of sites and sampling times into site/year groups. Site/year groupings were determined based on general agreement of the clustering and ordination techniques. Discriminant analysis was used to examine the degree to which key environmental variables could discriminate the site/year groups. The absolute magnitude of the standardized coefficients of the variables along the discriminant axes represent the contribution (i.e. importance) of each variable to an axis. Environmental variables used in the analysis were: percentage sand, percentage mud, TPAH, and chrysene concentrations. Percentage sand and mud were used because sediment grain-size characteristics are major determinants of community composition in marine benthic communities (e.g. Rhoads 1974, Grebmeier et al. 1989). Other environmental variables, including percentage gravel and various other hydrocarbon analytes (e.g. nonaromatics, dibenzothiophenes, fluorenes, naphthalenes, phenanthrenes, and alkanes), were excluded because (in the case of gravel) they were linearly dependent with percentage sand and mud or (in the case of other hydrocarbon analytes) were highly correlated ( $\mathrm{r}>0.9$ ) with either TPAH or chrysene concentrations. Percentage sand and mud variables were arcsine[square root $(x)$-transformed and chrysene and TPAH concentrations were $\ln (x)$-transformed. All 4 variables were considered in the discriminant analysis model, as opposed to stepwise procedures, so that the contribution of each variable to the discriminant axes could be assessed.

Univariate analyses were used to test for differences between oiled and reference sites, between years, and to examine possible interactions between oiling category and year. Metrics analyzed included TPAH and chrysene concentrations, and various community and individual taxon measures for the biological data. Community measures included total abundance, total biomass, Margalef's species richness index, SR (Green 1979), and Shannon's diversity index, $H^{\prime}$ (Shannon \& Weaver 1963). Taxa identified to the family level (or higher, i.e. class, order, phylum) were used in the cal- culation of richness and diversity. Analyses were also performed for dominant families and for some major higher taxonomic groupings. Dominant families were those that occurred in one-sixth or more of the samples and ranked among the 15 most abundant taxa in any given year and depth stratum.

Two-way randomization ANOVAs (Manly 1991) were used to test for differences between oiled and reference sites, between years, and for the interaction of oiling category and year, as described in Dean et al. (1996b). Oiling category (oiled or reference) and year were treated as fixed mean effects with pair as a random blocking factor Sites were treated as experimental units and site means were used as replicates in all analyses. Separate analyses were performed for each depth stratum, and for biological data, for infaunal and epifaunal species. Individual families were assigned to either infaunal or epifaunal groups according to the habitat of the dominant family within the group. In cases where the 2-way randomization ANOVA indicated a significant effect of oiling category or a significant interaction between oiling category and year, contrasts were made between oiled and reference sites within years. In the majority of the cases je.g. 23 of 45 families for which analyses were conducted) there was a significant effect of pair $(p<0.10)$, the random blocking factor. We do not report these because while they generally support our use of a matched-pair design, they do not influence our interpretation of the data with respect to the impacts of oil.

The percentage of mud was used as a covariate in some analyses of infaunal data. A preliminary 2-way ANOVA was performed using standard normal theory methods (without randomization) with percentage mud as a covariate. In cases where percentage mud contributed significantly to the model, with $\mathrm{p}<0.20$, we used mud as a covariate in the final randomization test. While probabilities associated with covariates were not exactly the same for the normal theory and randomization models, preliminary tests indicated that they were generally similar (usually within 0.02) and were deemed a reasonable and efficient means of evaluating whether to include mud as a covariate, and to avoid over parameterization in cases where the percentage mud was unlikely to contribute significantly.

We measured eelgrass shoot density in each sampling quadrat, but did not use this as a covariate for the following reasons. First, there were differences in eelgrass shoot density at oiled and reference sites and differences in the possible impact of the spill on eelgrass (Dean et al. 1998). Therefore, implications of spill impacts on benthic invertebrates could potentially be masked in analyses using eelgrass shoot density as a covariate. Second, using data from only refer- 
ence sites, we correlated the density of shoots from within each quadrat with the density of dominant families of benthic invertebrates and found no significant relationships. Squared correlation coefficients never exceeded 0.17 ( $n=35, p>0.13$ in all cases). Also, we did not use percentage sand as a covariate because preliminary analyses suggested that when percentage mud was also used as a covariate, percentage sand did not contribute significantly to the model, and its inclusion could lead to over-parameterization.

A Type I error rate of $p \leq 0.10$ was used for all analyses. This was done in an effort to balance Type I $(\alpha)$ and Type II ( $\beta$ ) error rates, and to insure that possible differences were not overlooked because of a lack of statistical power (high Type II error) (Eberhardt \& Thomas 1991, Mapstone 1995). Type II errors are those associated with the failure to correctly identify significant differences when they exist. High Type II error rates result from high variance and small sample sizes. We have not calculated power for our tests, but the large variation between sites, small sample size $(n=3)$, and the generally large differences between means in cases where statistically significant differences were observed suggest relatively low power. In all instances we report at least relative probabilities $(\mathrm{p} \leq 0.10, \mathrm{p} \leq$ 0.05 , or $\mathrm{p} \leq 0.01$ ).

\section{RESULTS}

\section{Hydrocarbons in sediments}

In 1990, over a year after the oil spill, mean TPAH concentrations were 4 to 8 times higher in sediments collected from sites adjacent to heavily oiled shorelines than at reference sites (Table 1), and the majority of samples from oiled sites had analyte compositions indicative of 'Exxon Valdez' oil (Table 2). The average TPAH concentration at oiled sites was approx. $5000 \mathrm{ng}$ $\mathrm{g}^{-1}$ and was significantly higher than at reference sites at each stratum $(p<0.02$ ) (Tables $2 \& 3$ ). There was however considerable variability between sites, with concentrations ranging from only $45 \mathrm{ng} \mathrm{g}^{-1}$ (at Herring Bay, 6 to $20 \mathrm{~m}$ depth) to over $15000 \mathrm{ng} \mathrm{g}^{-1}$ (at Bay of Isles, 6 to $20 \mathrm{~m}$ depth).

TPAH concentrations declined significantly over time at both oiled and reference sites (Tables $1 \& 3$ ). A significant interaction between oiling category and year for both depth strata resulted from the higher concentrations at oiled sites in 1990, and decline of TPAH concentrations at both oiled and reference sites to similarly low concentrations in 1995. In 1991, the majority of samples from oiled sites still had signatures indicative of 'Exxon Valdez' oil (Table 2), but mean concentrations had declined by more than $90 \%$. By 1993,

Table 1. Mean concentrations of (A) TPAHs and (B) chrysenes in shallow subtidal sediments in oiled (O) and reference (R) sites, Prince William Sound, 1990-95. BI: Bay of Isles, DB: Drier Bay, HB: Herring Bay, LHB: Lower Herring Bay, SB: Sleepy Bay, MB: Moose Lips Bay

\begin{tabular}{|c|c|c|c|c|c|c|c|c|}
\hline Year & $\mathrm{BI}(\mathrm{O})$ & $\mathrm{DB}(\mathrm{R})$ & $\mathrm{HB}(\mathrm{O})$ & LHB (R) & $\mathrm{SB}(\mathrm{O})$ & $\mathrm{MB}(\mathrm{R})$ & Oiled & Reference \\
\hline \multicolumn{9}{|l|}{ (A) } \\
\hline \multicolumn{9}{|c|}{ TPAH (ng g $\left.{ }^{-1}\right)$ at $6-20 \mathrm{~m}$} \\
\hline 1990 & 15253 & 1837 & 45 & 1908 & 872 & 102 & 5390 & 1282 \\
\hline 1991 & 1122 & 130 & 121 & 103 & 305 & 116 & 516 & 116 \\
\hline 1993 & 612 & 95 & 87 & 0 & 117 & 74 & 272 & 57 \\
\hline 1995 & 256 & 66 & 34 & 118 & 377 & 121 & 222 & 101 \\
\hline \multicolumn{9}{|c|}{ TPAH (ng g ${ }^{-1}$ ) at $<3 \mathrm{~m}$} \\
\hline 1990 & 14309 & 1418 & 322 & 297 & 306 & 124 & 4979 & 613 \\
\hline 1991 & 790 & 915 & 137 & 60 & 174 & 59 & 367 & 345 \\
\hline 1993 & 443 & 59 & 40 & 45 & 11 & 42 & 164 & 49 \\
\hline 1995 & 313 & 179 & 20 & 9 & 16 & 60 & 116 & 83 \\
\hline \multicolumn{9}{|l|}{ (B) } \\
\hline \multicolumn{9}{|c|}{ Chrysene $\left(\mathrm{ng} \mathrm{g}^{-1}\right)$ at $6-20 \mathrm{~m}$} \\
\hline 1990 & 16 & 6 & 3 & 3 & 54 & 3 & 24 & 4 \\
\hline 1991 & 21 & 6 & 2 & 0 & 14 & 2 & 12 & 3 \\
\hline 1993 & 32 & 5 & 3 & 0 & 13 & 2 & 16 & 2 \\
\hline 1995 & 5 & 0 & 5 & 7 & 23 & 5 & 11 & 4 \\
\hline \multicolumn{9}{|c|}{ Chrysene $\left(\mathrm{ng} \mathrm{g}^{-1}\right)$ at $<3 \mathrm{~m}$} \\
\hline 1990 & 42 & 2 & 15 & 1 & 9 & 2 & 22 & 2 \\
\hline 1991 & 9 & 2 & 2 & 0 & 7 & 1 & 6 & 1 \\
\hline 1993 & 17 & 0 & 3 & 0 & 1 & 2 & 7 & 1 \\
\hline 1995 & 16 & 3 & 1 & 0 & 1 & 1 & 6 & 2 \\
\hline
\end{tabular}


Table 2. Classification of sediment hydrocarbon samples, based on the presence of an 'Exxon Valdez' oil signature, from 2 depth strata in and adjacent to eelgrass beds

\begin{tabular}{|c|c|c|c|c|c|}
\hline \multirow[t]{2}{*}{ Year } & \multirow{2}{*}{$\begin{array}{c}\text { Oil/ } \\
\text { Reference }\end{array}$} & \multicolumn{2}{|c|}{ Deep $(6-20 \mathrm{~m})$} & \multicolumn{2}{|c|}{ Bed $(<3 \mathrm{~m})$} \\
\hline & & $\begin{array}{c}\text { No. of } \\
\text { samples }\end{array}$ & $\begin{array}{l}\text { No. with } \\
\text { 'Exxon } \\
\text { Valdez' oil }\end{array}$ & $\begin{array}{c}\text { No. of } \\
\text { samples }\end{array}$ & $\begin{array}{l}\text { No. with } \\
\text { 'Exxon } \\
\text { Valdez' oil }\end{array}$ \\
\hline \multirow[t]{2}{*}{1990} & $\mathrm{O}$ & 7 & 2 & 9 & 8 \\
\hline & $\mathrm{R}$ & 6 & 2 & 9 & 3 \\
\hline \multirow[t]{2}{*}{1991} & $\mathrm{O}$ & 9 & 7 & 9 & 6 \\
\hline & $\mathrm{R}$ & 8 & 5 & 9 & 2 \\
\hline \multirow[t]{2}{*}{1993} & $\mathrm{O}$ & 9 & 2 & 9 & 2 \\
\hline & $\mathrm{R}$ & 9 & 0 & 9 & 0 \\
\hline \multirow[t]{2}{*}{1995} & $\mathrm{O}$ & 9 & 1 & 9 & 1 \\
\hline & $\mathrm{R}$ & 9 & 0 & 9 & 0 \\
\hline
\end{tabular}

Table 3. Two-way ANOVA and contrasts of oiled versus reference sites within years for mean concentrations of (A) TPAHs and $(B)$ chrysenes in shallow subtidal sediments in oiled and reference sites, Prince William Sound, 1990-95

\begin{tabular}{|c|c|c|}
\hline & \multicolumn{2}{|c|}{ p-values } \\
\hline & $6-20 \mathrm{~m}$ & $<3 \mathrm{~m}$ \\
\hline \multicolumn{3}{|c|}{ (A) TPAH (ng g ${ }^{-1}$ ) } \\
\hline \multicolumn{3}{|c|}{ Source of variation } \\
\hline Oilcode & 0.01 & 0.02 \\
\hline Year & $<0.01$ & $<0.01$ \\
\hline Interaction & $<0.01$ & $<0.01$ \\
\hline \multicolumn{3}{|c|}{ Contrasts of oil vs reference within years } \\
\hline 1990 & 0.02 & 0.02 \\
\hline 1991 & 0.08 & 0.07 \\
\hline 1993 & $<0.01$ & $<0.01$ \\
\hline 1995 & 0.24 & 0.23 \\
\hline \multicolumn{3}{|c|}{ (B) Chrysene (ng g-1) } \\
\hline \multicolumn{3}{|c|}{ Source of variation } \\
\hline Oilcode & $<0.01$ & $<0.01$ \\
\hline Year & 0.15 & 0.15 \\
\hline Interaction & 0.13 & 0.13 \\
\hline \multicolumn{3}{|c|}{ Contrasts of oil vs reference within years } \\
\hline 1990 & $<0.01$ & $<0.01$ \\
\hline 1991 & $<0.01$ & $<0.01$ \\
\hline 1993 & $<0.01$ & $<0.01$ \\
\hline 1995 & 0.16 & 0.18 \\
\hline
\end{tabular}

average TPAH concentrations dropped to below 300 ng $\mathrm{g}^{-1}$ at oiled sites, and by 1995, averaged less than $230 \mathrm{ng} \mathrm{g}^{-1}$ at both oiled and reference sites and did not differ significantly between sites. However, there were still indications of slight exposure to oil in 1995, as 2 samples (1 from Bay of Isles and 1 from Sleepy Bay) had TPAH concentrations exceeding $300 \mathrm{ng} \mathrm{g}^{-1}$, and had signatures matching 'Exxon Valdez' oil.

A similar pattern was observed in total chrysenes, as concentrations were generally higher at oiled sites and appeared to decline over time (Table 1). Concentrations were significantly higher at oiled sites, but differences between years and interactions between years and oiling categories were not significant (Table 3). Within year contrasts showed that chrysene concentrations were significantly higher at oiled sites than at reference sites from 1990 through 1993, but not in 1995 .

There was moderate hydrocarbon contamination at reference sites. Relatively high concentrations of both TPAH and chrysenes were observed at reference sites in 1990 and 1991, and nearly one-third or more of the samples had signatures indicative of 'Exxon Valdez' oil (Table 2). At some reference sites, contamination was apparently from sources other than 'Exxon Valdez' oil. For example, the average concentration of TPAHs at 6 to $20 \mathrm{~m}$ depth at the Lower Herring Bay in 1990 was $1908 \mathrm{ng}^{-1}$, but none of the samples from there had analyte signatures characteristic of weathered 'Exxon Valdez' crude oil. The TPAH patterns were more evident of gasoline (possibly contaminated during collection), diesel oil (possibly from cleanup activities), submarine oil seeps (Page et al. 1995), or coal (Short et al. 1999).

\section{The benthic community - multivariate analyses}

Over 400 taxa (genera and species) of infaunal and small epifaunal invertebrates with representatives from over 151 families were collected. The infaunal community was numerically dominated by a variety of polychaetes, bivalve and gastropod mollusks, and crustaceans (mostly amphipods), an assemblage typical of infaunal communities from shallow mud and sand bottoms in subarctic waters (Feder \& Jewett 1987). Mytilid bivalves (Musculus spp.) and spirorbid polychaetes dominated the epifaunal community.

Cluster and MDS analyses (Fig. 2) indicated that, for both infauna and epifauna, there was greater spatial than temporal variability. In most instances samples collected from the same sites in different years tended to be more similar than samples collected from different sites in a given year. Also, there was a tendency for sites of a matched pair (e.g. Herring Bay and Lower Herring Bayl to cluster. Clusters of site/years were not as well defined for epifaunal communities in the 6 to $20 \mathrm{~m}$ depth stratum compared with infaunal communities and compared with the epifauna within the eelgrass bed.

Infauna in the deeper stratum at 1 oiled site, Bay of Isles, was remote in ordinate space from the majority of the other site/years, and the sample from 1990 was extremely remote compared with other years (Fig. 2). This site generally had higher hydrocarbon concentrations than other sites, and the mean concentration of 
6-20 m Infauna
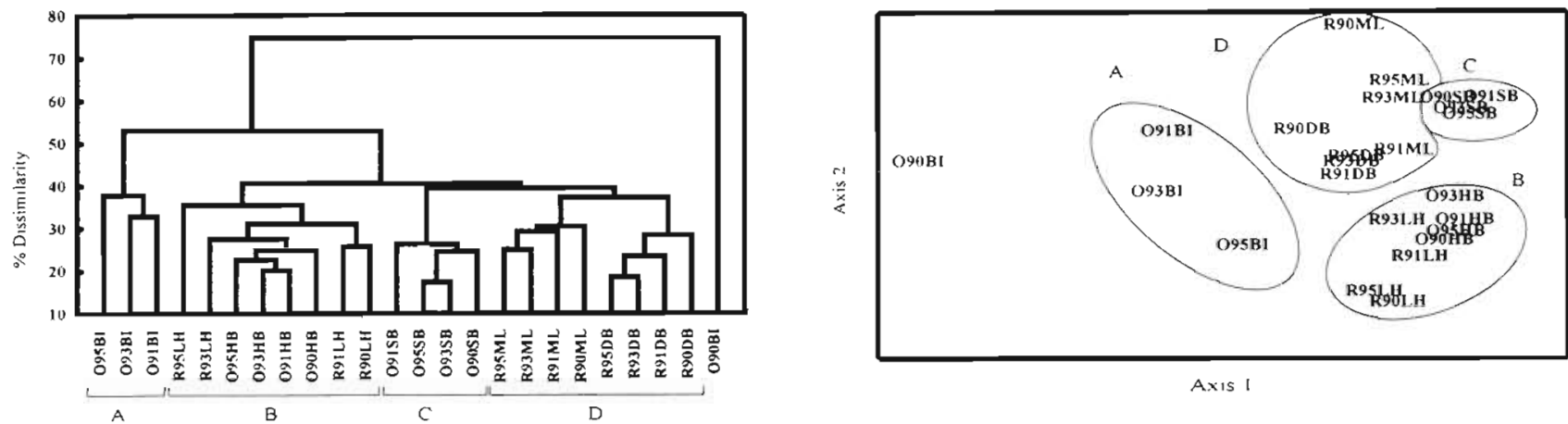

Axis 1

6-20 m Epifauna
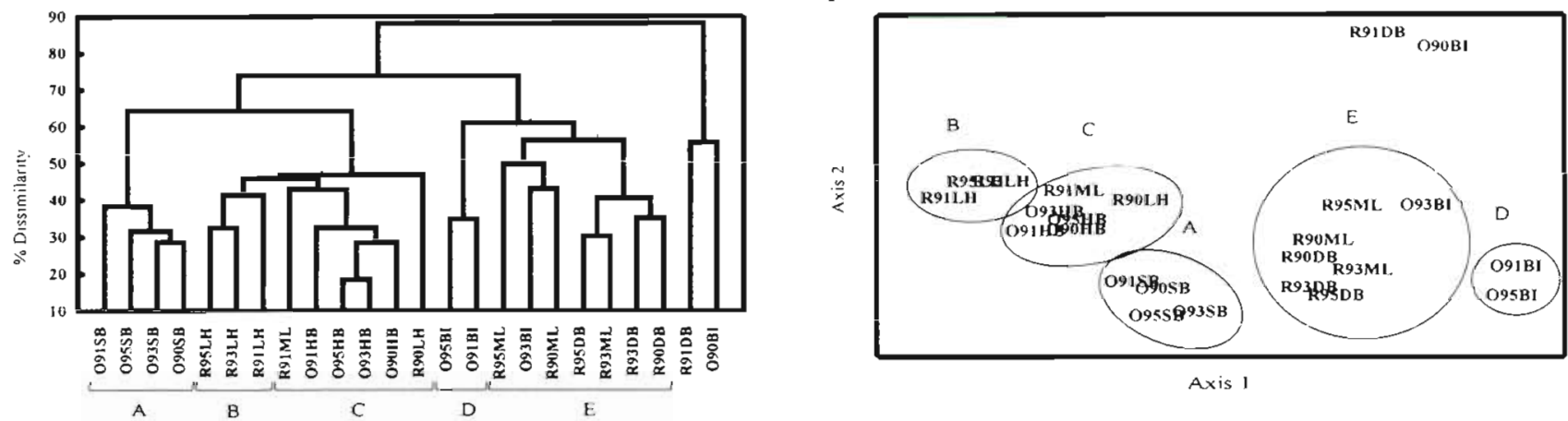

$<3$ m Infauna
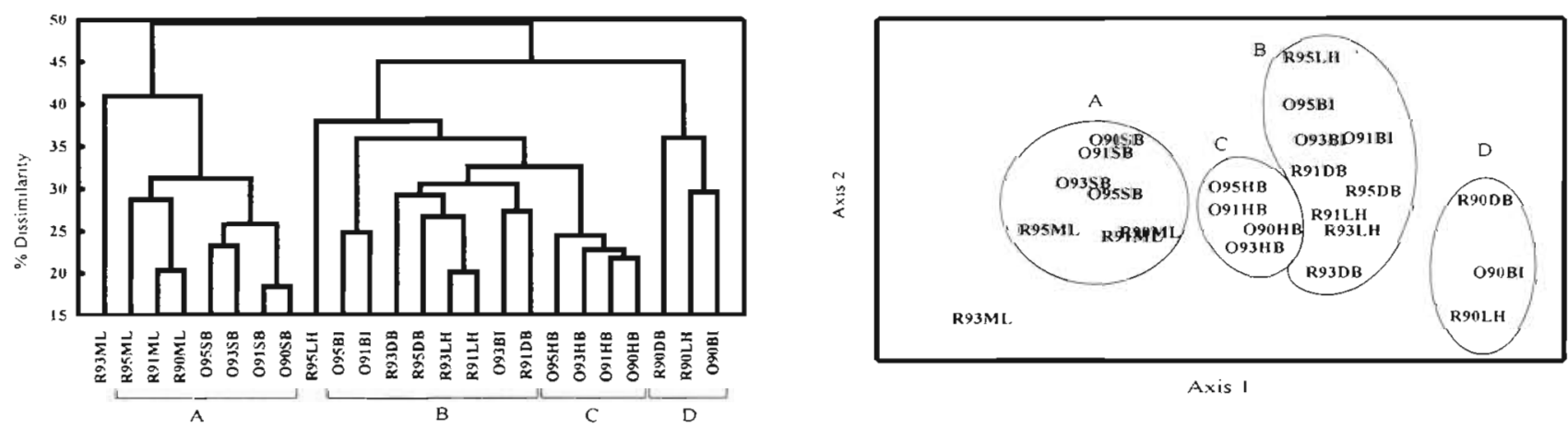

Axis I

$<3$ m Epifauna
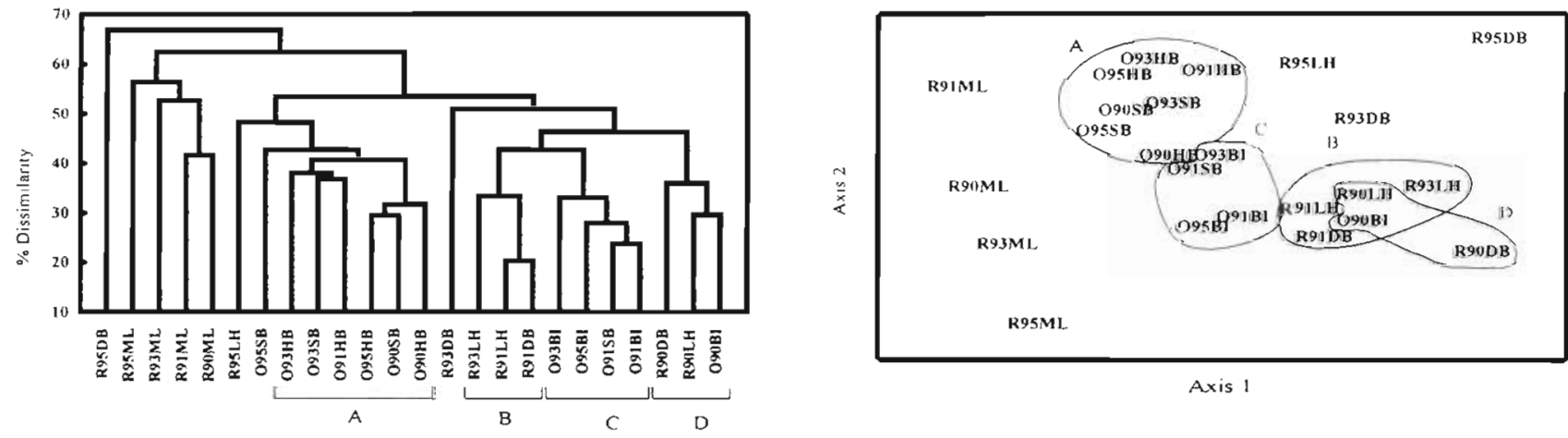

Fig. 2. Cluster dendrogram (left) and MDS ordination of ln-transformed abundance data (right) from infauna and epifauna in 2 depth strata. Site groups determined by cluster analysis are circled and labeled on the MDS ordination. Sites are labeled as O (oiled) or R (reference), year, and site. BI: Bay of Isles, LH: Lower Herring Bay, HB: Herring Bay, SB: Sleepy Bay, ML: Moose Lips Bay, DB: Drier Bay 
TPAH at Bay of Isles in 1990 (greater than $15000 \mathrm{ng} \mathrm{g}^{-1}$ ) was the highest concentration of TPAH observed (Table 1).

For infauna in the eelgrass bed $<3 \mathrm{~m}$ depth), 1990 samples from Bay of Isles, Drier Bay, and Lower Herring Bay were remote from other site/years (Fig. 2). Two of these were reference sites, but sediments from all 3 had high TPAH concentrations (14309 $\mathrm{ng} \mathrm{g}^{-1}$ at Bay of Isles, $1418 \mathrm{ng} \mathrm{g}^{-1}$ at Drier Bay, and $297 \mathrm{ng} \mathrm{g}^{-1}$ at Lower Herring Bay), and 2 of the 3 (Bay of Isles, Drier Bay) had the highest concentrations.

There was little evidence of convergence between communities at matched pairs of oiled and reference sites over time. Levels of dissimilarity decreased markedly between 1990 and 1995 for the infaunal community at the 6 to $20 \mathrm{~m}$ depth at Bay of Isles and Drier Bay. Otherwise, there were no substantial decreases in dissimilarity over time (Table 4). In fact, some pairs of sites, and especially epifauna at $<3 \mathrm{~m}$ at Bay of Isles and Drier Bay, became more dissimilar with time.

Discriminant analyses suggest that sediment characteristics and chrysene concentrations were important in distinguishing site/year groupings indicated by cluster and MDS analyses. In analyses using percentage sand, percentage mud, TPAH concentrations, and chrysene concentrations as potential explanatory variables, at least $91 \%$ the variance in the community composition was explained by the first 2 discriminant axes (Table 5). The percentage of correct classifications ranged from 91 to $100 \%$, indicating a strong relationship between the distributions of the variables and the site/year groupings for each data set. In all but the epifaunal community within the eelgrass bed, percentage mud and sand were highly significant contributors to the discriminant model $(p \leq$ 0.01). Chrysenes were also important contributors (i.e. $p \leq 0.1$ ) in all but the infaunal community at $<3 \mathrm{~m}$ and had the highest standardized coefficients for most analyses. TPAH was never a significant contributor to the discriminant model.

The relationships between environmental variables and community structure are also evident in overlays of environmental variables on the MDS ordinations (Fig. 3). Site/year groupings generally exhibited values of percentage sand and mud of similar magnitudes, with values increasing from left
Table 4. Percentage dissimilarity between pairs of oiled and reference sites over time and the change in percentage dissimilarity between 1990 and 1995. BI: Bay of Isles, DB: Drier Bay, HB: Herring Bay, LH: Lower Herning Bay, SB: Sleepy Bay, ML: Moose Lips Bay

\begin{tabular}{|ccrrrrrr|}
\hline \multirow{2}{*}{ Depth } & Year & \multicolumn{3}{c}{ Infauna } & \multicolumn{3}{c|}{ Epifauna } \\
& & Bl/DB & HB/LH & SB/ML & Bl/DB & HB/LH & SB/ML \\
\hline $6-20 \mathrm{~m}$ & 1990 & 68 & 30 & 41 & 65 & 46 & 61 \\
& 1991 & 44 & 26 & 39 & 82 & 40 & 56 \\
& 1993 & 49 & 26 & 35 & 71 & 38 & 62 \\
& 1995 & 36 & 33 & 34 & 72 & 47 & 75 \\
& $\%$ Change & -32 & 3 & -7 & 7 & 1 & 14 \\
$<3 \mathrm{~m}$ & 1990 & 35 & 42 & 31 & 36 & 46 & 46 \\
& 1991 & 33 & 29 & 33 & 33 & 50 & 52 \\
& 1993 & 33 & 30 & 41 & 41 & 60 & 59 \\
& 1995 & 37 & 34 & 30 & 71 & 46 & 67 \\
$\%$ Change & 2 & -8 & -1 & 35 & 0 & 21 \\
\hline
\end{tabular}

Table 5. Results from discriminant analyses of environmental variables for shallow subtidal sites in and adjacent to eelgrass beds in Prince William Sound, 1990, 1991, 1993, and 1995. F: Fstatistic, p-value: significance of $F$ statistic, Sig. Ax.: significance of derived axis, \% Var.: cumulative percent of variance accounted for by each axis, \% Corr.: percent of correct classifications of original data by the discriminant functions

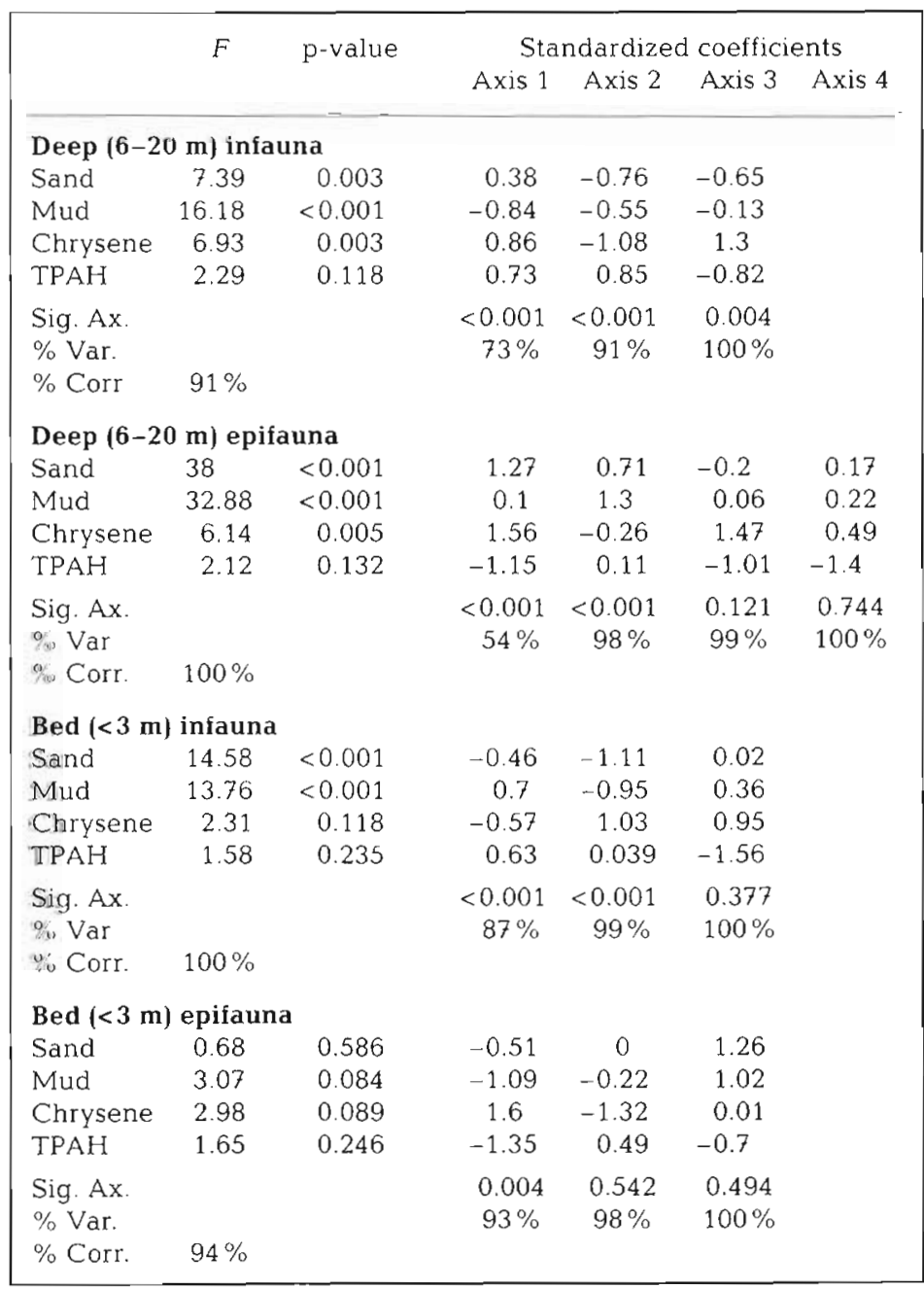



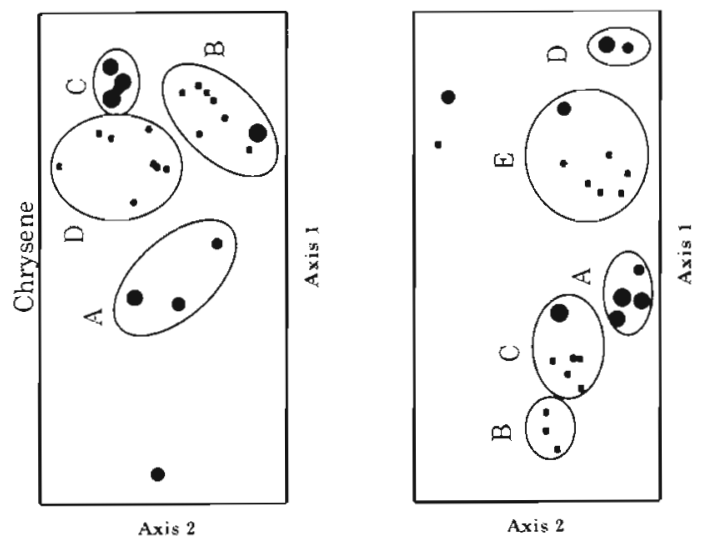

Axis 2
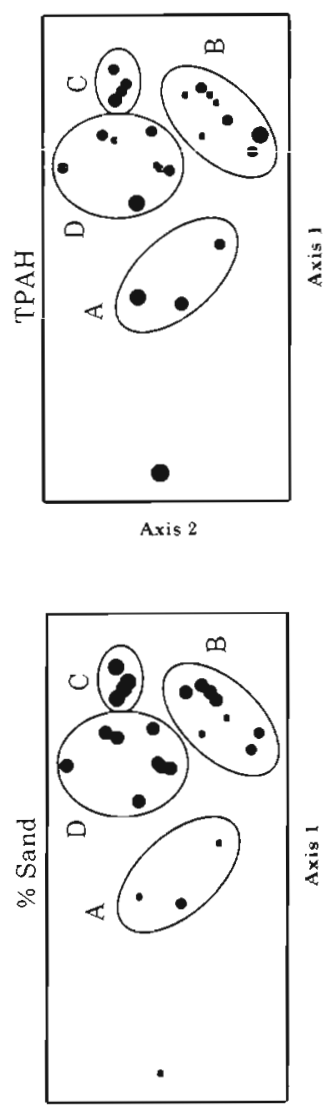

Axis 2
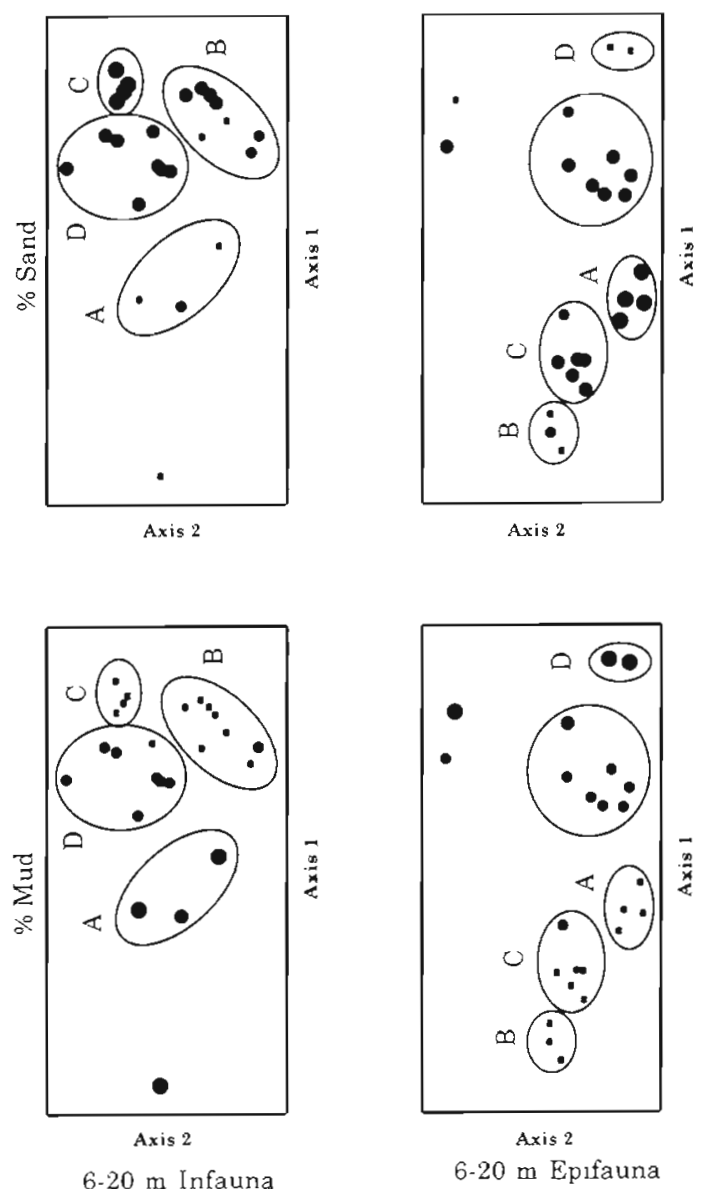

Axis 2

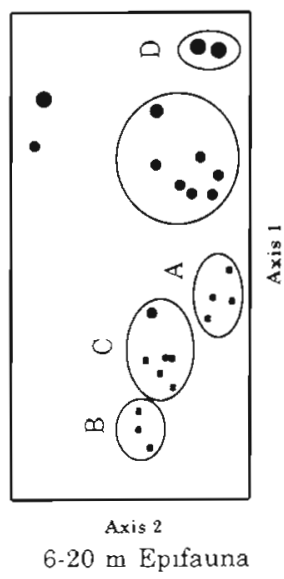

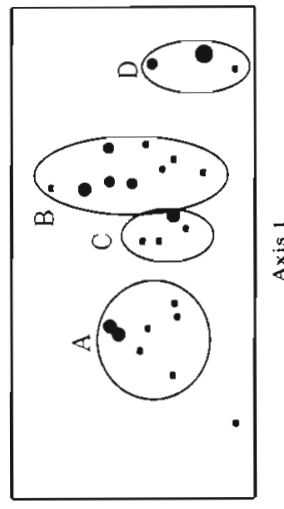

Axis 2
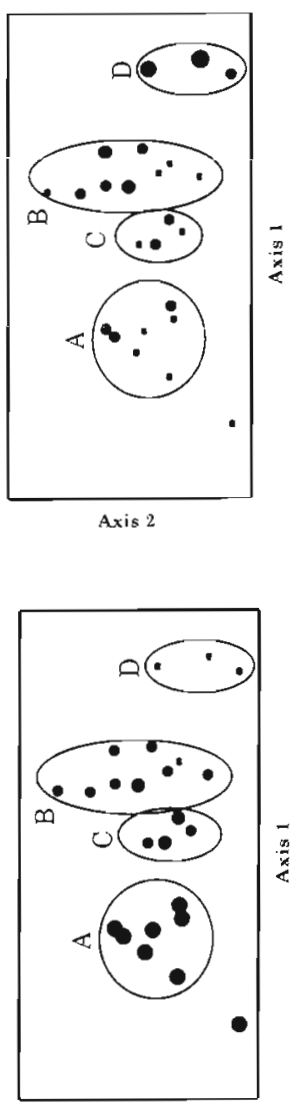

Axis 2

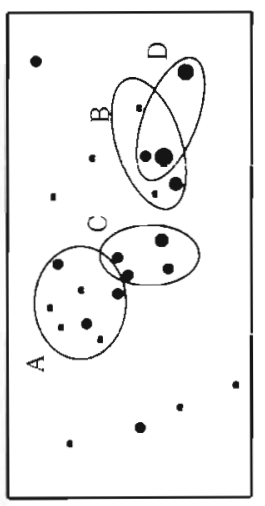

Axis 2

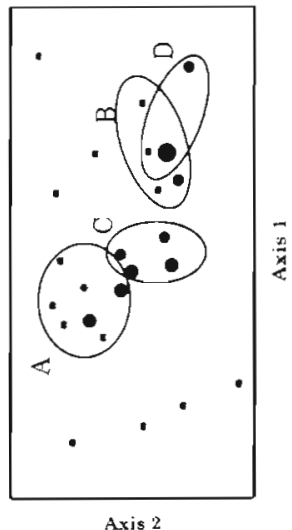

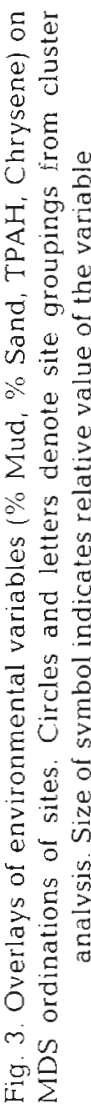

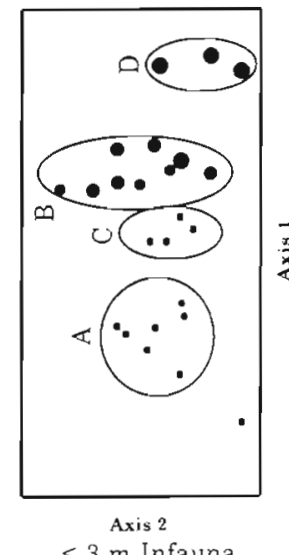

$<3$ m Infauna
Axis 2
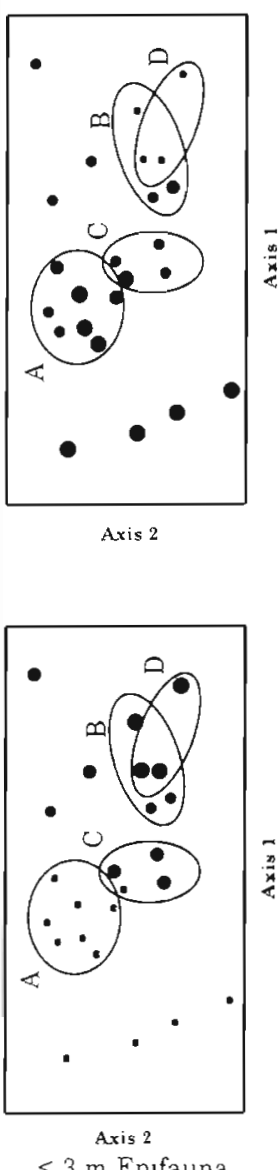
to right, particularly for percentage mud. There was a less obvious correspondence of site/year groupings with magnitudes of chrysenes or TPAHs, but samples within a site/year group or within adjacent groups generally had similar TPAH and chrysene concentrations.

\section{Community parameters and the abundance of higher taxonomic groups}

The most consistent pattern among community parameters was the significantly higher total abundance and biomass of epifauna at oiled than at reference sites at both depth strata (Tables 6 \& 7). Also, there were significant interactions between oiling category and year for epifaunal total abundance in both depth strata, and for epifaunal total biomass at 6 to $20 \mathrm{~m}$. Biomass of epifauna at $<3 \mathrm{~m}$ was significantly higher at oiled sites in 1990 and 1991, but not thereafter. Otherwise, there were no consistent temporal trends in epifaunal abundance or biomass. Total abundance and biomass of infauna also differed significantly between oiled and reference sites, but the direction differed with depth. Both abundance and biomass were higher at reference sites at 6 to $20 \mathrm{~m}$, and higher at oiled sites at $<3 \mathrm{~m}$. Total abundance of infauna at the shallow depth was higher at oiled sites in 1993 and 1995, but not prior. Otherwise, there were no consistent temporal trends and there were no significant interactions between oiling category and year for infauna. Shannon diversity $\left(H^{\prime}\right)$ of epifauna was higher at oiled sites within the eelgrass bed, but otherwise, there were no significant effects of oiling category for diversity measures ( $H^{\prime}$ or species richness).

The greater overall abundance of epifauna at oiled sites was mostly attributable to a greater abundance of bivalves (Tables $8 \& 9$ ). There were significantly more epifaunal bivalves at oiled sites at both depth strata ( $\mathrm{p} \leq 0.01$ for both). At $<3 \mathrm{~m}$ there were also significantly higher densities of epifaunal gastropods and echinoderms at oiled sites. For infauna, there were higher densities of polychaetes and gastropods at oiled sites in both depth strata. Significant interactions between oiling category and year were evident for other crustacean infauna (i.e. cumaceans, isopods) at both depth strata, and epifauna at $<3 \mathrm{~m}$, as well as for epifaunal polychaetes, amphipods, and echinoderms in the eelgrass bed. However, none showed consistent temporal trends. Only infaunal amphipods within the eelgrass bed were more abundant at reference sites $(\mathrm{p} \leq 0.05$ ). Densities of infaunal amphipods at $<3 \mathrm{~m}$ were significantly higher at reference sites in 1990, but not in subsequent years.

\section{The abundance of individual families}

Of the 25 dominant families in the 6 to $20 \mathrm{~m}$ depth stratum, and the 22 dominant families within the eelgrass bed, over half had densities that differed significantly between oiled and reference sites, or displayed a significant interaction between oiling category and year (Tables $10 \& 11$ ). Some were more abundant at reference sites, some were more abundant at oiled

Table 6. Mean values of community parameters for benthic invertebrates at oiled $(O)$ and reference $(R)$ sites in and adjacent to eelgrass beds in Prince William Sound, 1990, 1991 1993, and 1995

\begin{tabular}{|c|c|c|c|c|c|}
\hline $\begin{array}{l}\text { Community } \\
\text { parameters }\end{array}$ & $\mathrm{O} / \mathrm{R}$ & 1990 & 1991 & 1993 & 1995 \\
\hline \multicolumn{6}{|c|}{$6-20 \mathrm{~m}$ infauna } \\
\hline \multirow{2}{*}{$\begin{array}{l}\text { Shannon } \\
\text { diversity }\end{array}$} & 0 & 2.14 & 2.36 & 2.58 & 2.52 \\
\hline & $\mathrm{R}$ & 2.42 & 2.53 & 2.44 & 2.65 \\
\hline \multirow{2}{*}{$\begin{array}{l}\text { Species } \\
\text { richness }\end{array}$} & 0 & 5.45 & 5.35 & 5.76 & 6.22 \\
\hline & $\mathrm{R}$ & 4.65 & 5.84 & 6.07 & 6.63 \\
\hline \multirow{2}{*}{$\begin{array}{l}\text { Total abund. } \\
\text { (no. } 0.1 \mathrm{~m}^{-2} \text { ) }\end{array}$} & 0 & 472 & 958 & 1018 & 1042 \\
\hline & $\mathrm{R}$ & 655 & 1185 & 1579 & 1021 \\
\hline \multirow{2}{*}{$\begin{array}{l}\text { Total biom. } \\
\left(\mathrm{g} \mathrm{dw} 0.1 \mathrm{~m}^{-2} \text { ) }\right.\end{array}$} & $\mathrm{O}$ & 6.22 & 6.17 & 7.38 & 7.79 \\
\hline & $\mathrm{R}$ & 6.57 & 13.95 & 13.63 & 10.70 \\
\hline \multicolumn{6}{|c|}{ 6-20 m epifauna } \\
\hline \multirow{2}{*}{$\begin{array}{l}\text { Shannon } \\
\text { diversity }\end{array}$} & $\mathrm{O}$ & 0.73 & 1.04 & 0.97 & 0.93 \\
\hline & $\mathrm{R}$ & 0.44 & 0.97 & 1.15 & 1.01 \\
\hline \multirow{2}{*}{$\begin{array}{l}\text { Species } \\
\text { richness }\end{array}$} & $\mathrm{O}$ & 1.49 & 2.44 & 1.47 & 1.16 \\
\hline & $\mathrm{R}$ & 1.33 & 1.63 & 2.85 & 1.75 \\
\hline \multirow{2}{*}{$\begin{array}{l}\text { Total abund. } \\
\text { (no. } 0.1 \mathrm{~m}^{-2} \text { ) }\end{array}$} & $\mathrm{O}$ & 97 & 123 & 240 & 386 \\
\hline & $\mathrm{R}$ & 41 & 127 & 49 & 39 \\
\hline \multirow{2}{*}{$\begin{array}{l}\text { Total biom. } \\
\left(\mathrm{g} \mathrm{dw} 0.1 \mathrm{~m}^{-2} \text { ) }\right.\end{array}$} & $\mathrm{O}$ & 0.72 & 1.50 & 2.36 & 7.19 \\
\hline & $\mathrm{R}$ & 0.16 & 2.67 & 1.15 & 0.44 \\
\hline \multicolumn{6}{|l|}{$<3 \mathrm{~m}$ infauna } \\
\hline \multirow{2}{*}{$\begin{array}{l}\text { Shannon } \\
\text { diversity }\end{array}$} & $\mathrm{O}$ & 2.03 & 2.19 & 2.40 & 2.36 \\
\hline & $\mathrm{R}$ & 2.12 & 2.32 & 2.24 & 2.40 \\
\hline \multirow{2}{*}{$\begin{array}{l}\text { Species } \\
\text { richness }\end{array}$} & $\mathrm{O}$ & 3.80 & 4.44 & 4.73 & 4.62 \\
\hline & $\mathrm{R}$ & 3.25 & 4.15 & 3.57 & 5.09 \\
\hline \multirow{2}{*}{$\begin{array}{l}\text { Total abund. } \\
\text { (no. } 0.1 \mathrm{~m}^{-2} \text { ) }\end{array}$} & 0 & 1030 & 1753 & 1717 & 1484 \\
\hline & $\mathrm{R}$ & 497 & 1963 & 822 & 645 \\
\hline \multirow{2}{*}{$\begin{array}{l}\text { Total biom. } \\
\left(\mathrm{g} \mathrm{dw} 0.1 \mathrm{~m}^{-2}\right)\end{array}$} & $\mathrm{O}$ & 6.90 & 4.88 & 13.00 & 5.75 \\
\hline & $\mathrm{R}$ & 3.01 & 7.66 & 3.43 & 2.75 \\
\hline \multicolumn{6}{|l|}{ <3 m epifauna } \\
\hline \multirow{2}{*}{$\begin{array}{l}\text { Shannon } \\
\text { diversity }\end{array}$} & $\mathrm{O}$ & 0.67 & 0.76 & 0.86 & 1.06 \\
\hline & $\mathrm{R}$ & 0.51 & 0.68 & 0.87 & 0.68 \\
\hline \multirow{2}{*}{$\begin{array}{l}\text { Species } \\
\text { richness }\end{array}$} & 0 & 1.01 & 0.83 & 1.06 & 1.04 \\
\hline & $\mathrm{R}$ & 0.83 & 0.94 & 1.39 & 0.23 \\
\hline \multirow{2}{*}{$\begin{array}{l}\text { Total abund } \\
\text { (no. } 0.1 \mathrm{~m}^{-2} \text { ) }\end{array}$} & 0 & 601 & 863 & 2123 & 769 \\
\hline & $\mathrm{R}$ & 191 & 465 & 268 & 1015 \\
\hline \multirow{2}{*}{$\begin{array}{l}\text { Total biom. } \\
\left(\mathrm{g} \mathrm{dw} 0.1 \mathrm{~m}^{-2} \text { ) }\right.\end{array}$} & 0 & 1.71 & 2.73 & 5.42 & 2.11 \\
\hline & $\mathrm{R}$ & 0.33 & 1.17 & 3.13 & 1.48 \\
\hline
\end{tabular}


Table 7 Summary of randomization ANOVAs for benthic invertebrate community parameters. Covariates used in the analyses are listed. Also given are contrasts between oiled and reference sites within years for those instances where there was a significant effect of oil category or a significant interaction between oil category and year

\begin{tabular}{|c|c|c|c|c|c|c|c|c|}
\hline & \multirow[t]{2}{*}{ Covariate } & \multicolumn{3}{|c|}{ 2-way randomization ANOVA } & \multicolumn{4}{|c|}{ Within year contrasts } \\
\hline & & Oil category & Year & Interaction & 1990 & 1991 & 1993 & 1995 \\
\hline \multicolumn{9}{|l|}{ Deep $(6-20 \mathrm{~m})$} \\
\hline \multicolumn{9}{|l|}{ Infauna } \\
\hline Shannon diversity & None & - & - & - & & & & \\
\hline Total abundance & Mud & 0 & $x x$ & - & - & - & - & - \\
\hline Total biomass & None & 000 & - & - & - & 0 & - & - \\
\hline Species richness & Mud & - & - & - & & & & \\
\hline \multicolumn{9}{|l|}{ Epifauna } \\
\hline Shannon diversity & None & - & $x$ & - & & & & \\
\hline Total abundance & None & $\bullet$ & - & $x x$ & - & - & - & $\bullet$ \\
\hline Total biomass & None & - & - & $x x$ & 0 & - & - & 0 \\
\hline Species richness & None & - & - & $x$ & - & - & O० & - \\
\hline \multicolumn{9}{|l|}{ Eelgrass bed $(<3 \mathrm{~m})$} \\
\hline \multicolumn{9}{|l|}{ Iníauná } \\
\hline Shannon diversity & None & - & $x x$ & - & & & & \\
\hline Total abundance & Mud & 00 & - & - & - & - & $\bullet$ & $\bullet$ \\
\hline Total biomass & None & - & - & - & - & - & - & 0 \\
\hline Species richness & None & - & $x X X$ & - & & & & \\
\hline \multicolumn{9}{|l|}{ Epifauna } \\
\hline Shannon diversity & None & 0 & $x$ & - & - & - & - & 0 \\
\hline Total abundance & None & 00 & $x$ & $x x x$ & 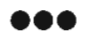 & 0 & 00 & - \\
\hline Total biomass & None & $\bullet \bullet$ & $x x$ & - & $\bullet$ & $\bullet$ & - & - \\
\hline Species richness & None & - & $x$ & - & & & & \\
\hline \multicolumn{2}{|c|}{$\begin{array}{l}\mathbf{O}=\text { greater at oiled sites } \\
\mathbf{O}=\text { greater at control sites } \\
X=\text { significant difference sites }\end{array}$} & \multicolumn{3}{|c|}{$\begin{array}{l}0,000, x x x \\
0,00, x x \\
, 0, x \\
-\end{array}$} & & & & \\
\hline
\end{tabular}

sites, and some had a significant oiling/year interaction. The most well represented group was composed of families that tended to be more abundant at oiled sites. This included 1 epifaunal bivalve (Mytilidae within both depth strata), 2 infaunal gastropods (Caecidae at 6 to $20 \mathrm{~m}$ and Lacunidae at $<3 \mathrm{~m}$ ), 2 infaunal bivalves (Montacutidae and Turtoniidae at $<3 \mathrm{~m}$ ), and 9 infaunal polychaete families (Spionidae at both depths; Maldanidae, Nephtyidae, and Syllidae at 6 to $20 \mathrm{~m}$; Amphictenidae, Nereidae, Opheliidae, Sabellidae, and Sigalionidae at $<3 \mathrm{~m}$ ) (Tables $10 \& 11$ ). As indicated in abundance patterns for mytilids, and representative families of dominant polychaetes and gastropods (Fig. 4), all were consistently more abundant at oiled sites from 1990 through 1995. There was little or no indication of declining abundances at oiled sites, or increases at reference sites over time.

The second group, with greater abundance at references sites, was represented by 2 infaunal amphipod families, 3 families of infaunal bivalves, and 2 infaunal polychaete families. Isaeid and phoxocephalid amphipods were more abundant $(p \leq 0.1)$ at reference sites (generally $>20$ ind. $0.1 \mathrm{~m}^{-2}$ ) in both depth strata (Fig. 5, Tables $10 \& 11$ ), and there were very few isaeids or phoxocephalids at oiled sites, especially in 1990. Both families showed some marginal increase in abundance at oiled sites over time, but the interaction between the oiling category and year was significant only for phoxocephalids at 6 to $20 \mathrm{~m}$. By 1995, only phoxocephalids were more abundant at reference sites within the eelgrass bed ( $\mathrm{p} \leq 0.01)$, but both families were still about 10 times more abundant at reference sites at both depth strata. Infaunal bivalve families (including Lucinidae, Montacutidae, and Thyasiridae in the 6 to $20 \mathrm{~m}$ stratum, and Tellinidae within the eelgrass bed) and polychaetes (Lumbrineridae and Opheliedae at 6 to $20 \mathrm{~m}$ ) were also more abundant at reference sites (Fig. 6, Tables 10 \& 11). Some of these (e.g. Montacutidae and Thyasiridae) showed marginal increases in abundance at oiled sites between 1990 and 1995, but none had significant interactions between oiling category and year.

The remaining group consisted of those families for which there was a significant oiling category by year 
Table 8. Mean densities (no. $0.1 \mathrm{~m}^{-2}$ ) for major taxonomic groups of benthic invertebrates at oiled $(O)$ and reference $(R)$ sites in and adjacent to eelgrass beds in Prince William Sound, 1990, 1991, 1992, and 1995

\begin{tabular}{|c|c|c|c|c|c|}
\hline $\begin{array}{l}\text { Taxon } \\
\text { groups }\end{array}$ & $\mathrm{O} / \mathrm{R}$ & 1990 & 1991 & 1993 & 1995 \\
\hline $\begin{array}{l}6-20 \mathrm{~m} \text { infauna } \\
\text { Polychaeta }\end{array}$ & $\begin{array}{l}\mathrm{O} \\
\mathrm{R}\end{array}$ & $\begin{array}{l}263 \\
297\end{array}$ & $\begin{array}{l}606 \\
590\end{array}$ & $\begin{array}{l}688 \\
930\end{array}$ & $\begin{array}{l}692 \\
349\end{array}$ \\
\hline Gastropoda & $\begin{array}{l}\mathrm{O} \\
\mathrm{R}\end{array}$ & $\begin{array}{l}73 \\
31\end{array}$ & $\begin{array}{r}171 \\
79\end{array}$ & $\begin{array}{l}75 \\
38\end{array}$ & $\begin{array}{r}105 \\
20\end{array}$ \\
\hline Bivalvia & $\begin{array}{l}\mathrm{O} \\
\mathrm{R}\end{array}$ & $\begin{array}{r}87 \\
260\end{array}$ & $\begin{array}{r}74 \\
412\end{array}$ & $\begin{array}{l}129 \\
541\end{array}$ & $\begin{array}{l}117 \\
499\end{array}$ \\
\hline Amphipoda & $\begin{array}{l}\mathrm{O} \\
\mathrm{R}\end{array}$ & $\begin{array}{l}21 \\
52\end{array}$ & $\begin{array}{l}40 \\
54\end{array}$ & $\begin{array}{l}64 \\
28\end{array}$ & $\begin{array}{c}61 \\
101\end{array}$ \\
\hline Other Crustacea & $\begin{array}{l}\mathrm{O} \\
\mathrm{R}\end{array}$ & $\begin{array}{l}22 \\
10\end{array}$ & $\begin{array}{l}23 \\
31\end{array}$ & $\begin{array}{l}28 \\
20\end{array}$ & $\begin{array}{l}24 \\
33\end{array}$ \\
\hline Echinodermata & $\begin{array}{l}\mathrm{O} \\
\mathrm{R}\end{array}$ & $\begin{array}{l}5 \\
3\end{array}$ & $\begin{array}{l}19 \\
11\end{array}$ & $\begin{array}{l}13 \\
16\end{array}$ & $\begin{array}{r}20 \\
7\end{array}$ \\
\hline $\begin{array}{l}\text { 6-20 m epifauna } \\
\text { Polychaeta }\end{array}$ & $\begin{array}{l}\mathrm{O} \\
\mathrm{R}\end{array}$ & $\begin{array}{l}27 \\
21\end{array}$ & $\begin{array}{l}28 \\
78\end{array}$ & $\begin{array}{l}39 \\
25\end{array}$ & $\begin{array}{l}36 \\
23\end{array}$ \\
\hline Gastropoda & $\begin{array}{l}\mathrm{O} \\
\mathrm{R}\end{array}$ & $\begin{array}{l}1 \\
1\end{array}$ & $\begin{array}{l}11 \\
13\end{array}$ & $\begin{array}{l}4 \\
6\end{array}$ & $\begin{array}{l}8 \\
2\end{array}$ \\
\hline Bivalvia & $\begin{array}{l}\mathrm{O} \\
\mathrm{R}\end{array}$ & $\begin{array}{r}50 \\
3\end{array}$ & $\begin{array}{r}39 \\
3\end{array}$ & $\begin{array}{r}171 \\
1\end{array}$ & $\begin{array}{r}290 \\
1\end{array}$ \\
\hline Amphipoda & $\begin{array}{l}\mathrm{O} \\
\mathrm{R}\end{array}$ & $\begin{array}{l}6 \\
8\end{array}$ & $\begin{array}{l}22 \\
14\end{array}$ & $\begin{array}{r}14 \\
5\end{array}$ & $\begin{array}{r}10 \\
1\end{array}$ \\
\hline Other Crustacea & $\begin{array}{l}\mathrm{O} \\
\mathrm{R}\end{array}$ & $\begin{array}{l}5 \\
5\end{array}$ & $\begin{array}{r}1 \\
12\end{array}$ & $\begin{array}{l}4 \\
3\end{array}$ & $\begin{array}{c}10 \\
2\end{array}$ \\
\hline Echinodermata & $\begin{array}{l}\mathrm{O} \\
\mathrm{R}\end{array}$ & $\begin{array}{r}1 \\
<1\end{array}$ & $\begin{array}{l}1 \\
1\end{array}$ & $\begin{array}{r}0 \\
<1\end{array}$ & $\begin{array}{r}<1 \\
1\end{array}$ \\
\hline $\begin{array}{l}<3 \text { m infauna } \\
\text { Polychaeta }\end{array}$ & $\begin{array}{l}\mathrm{O} \\
\mathrm{R}\end{array}$ & $\begin{array}{l}503 \\
200\end{array}$ & $\begin{array}{l}771 \\
981\end{array}$ & $\begin{array}{l}810 \\
474\end{array}$ & $\begin{array}{l}650 \\
192\end{array}$ \\
\hline Gastropoda & $\begin{array}{l}\mathrm{O} \\
\mathrm{R}\end{array}$ & $\begin{array}{l}305 \\
106\end{array}$ & $\begin{array}{l}465 \\
344\end{array}$ & $\begin{array}{l}263 \\
111\end{array}$ & $\begin{array}{l}367 \\
177\end{array}$ \\
\hline Bivalvia & $\begin{array}{l}\mathrm{O} \\
\mathrm{R}\end{array}$ & $\begin{array}{l}174 \\
103\end{array}$ & $\begin{array}{l}450 \\
163\end{array}$ & $\begin{array}{l}448 \\
119\end{array}$ & $\begin{array}{l}333 \\
100\end{array}$ \\
\hline Amphipoda & $\begin{array}{l}\mathrm{O} \\
\mathrm{R}\end{array}$ & $\begin{array}{l}25 \\
81\end{array}$ & $\begin{array}{r}37 \\
226\end{array}$ & $\begin{array}{r}116 \\
96\end{array}$ & $\begin{array}{r}68 \\
133\end{array}$ \\
\hline Other Crustacea & $\begin{array}{l}\mathrm{O} \\
\mathrm{R}\end{array}$ & $\begin{array}{r}16 \\
4\end{array}$ & $\begin{array}{l}13 \\
39\end{array}$ & $\begin{array}{l}49 \\
12\end{array}$ & $\begin{array}{l}37 \\
35\end{array}$ \\
\hline Echınodermata & $\begin{array}{l}\mathrm{O} \\
\mathrm{R}\end{array}$ & $\begin{array}{l}1 \\
2\end{array}$ & $\begin{array}{l}2 \\
3\end{array}$ & $\begin{array}{r}15 \\
5\end{array}$ & $\begin{array}{l}6 \\
5\end{array}$ \\
\hline $\begin{array}{l}<3 \text { m epifauna } \\
\text { Polychaeta }\end{array}$ & $\begin{array}{l}\mathrm{O} \\
\mathrm{R}\end{array}$ & $\begin{array}{r}370 \\
80\end{array}$ & $\begin{array}{l}290 \\
157\end{array}$ & $\begin{array}{r}729 \\
71\end{array}$ & $\begin{array}{l}288 \\
925\end{array}$ \\
\hline Gastropoda & $\begin{array}{l}\mathrm{O} \\
\mathrm{R}\end{array}$ & $\begin{array}{l}7 \\
2\end{array}$ & $\begin{array}{l}6 \\
2\end{array}$ & $\begin{array}{r}14 \\
3\end{array}$ & $\begin{array}{l}8 \\
5\end{array}$ \\
\hline Bivalvia & $\begin{array}{l}\mathrm{O} \\
\mathrm{R}\end{array}$ & $\begin{array}{r}163 \\
13\end{array}$ & $\begin{array}{r}447 \\
67\end{array}$ & $\begin{array}{r}729 \\
16\end{array}$ & $\begin{array}{r}340 \\
4\end{array}$ \\
\hline Amphipoda & $\begin{array}{l}\mathrm{O} \\
\mathrm{R}\end{array}$ & $\begin{array}{l}52 \\
94\end{array}$ & $\begin{array}{l}118 \\
233\end{array}$ & $\begin{array}{l}644 \\
172\end{array}$ & $\begin{array}{l}93 \\
76\end{array}$ \\
\hline Other Crustacea & $\begin{array}{l}\mathrm{O} \\
\mathrm{R}\end{array}$ & $\begin{array}{l}3 \\
2\end{array}$ & $\begin{array}{r}<1 \\
1\end{array}$ & $\begin{array}{l}5 \\
2\end{array}$ & $\begin{array}{l}2 \\
3\end{array}$ \\
\hline Echinodermata & $\begin{array}{l}\mathrm{O} \\
\mathrm{R}\end{array}$ & $\begin{array}{l}4 \\
0\end{array}$ & $\begin{array}{r}<1 \\
0\end{array}$ & $\begin{array}{l}2 \\
1\end{array}$ & $\begin{array}{r}7 \\
<1\end{array}$ \\
\hline
\end{tabular}

interaction, but no significant effect of oiling category. This included 2 polychaetes (Syllidae and Spirorbidae) and 2 amphipods (Ischyroceridae and Caprellidae) at $<3 \mathrm{~m}$ (Fig. 7, Table 11). Both polychaetes showed relative increases at reference sites over time. For the 2 amphipod families, there was relatively few individuals at either oiled or reference sites in 1990, a peak in abundance at reference sites in 1991, and a peak at oiled sites in 1993.

\section{DISCUSSION}

\section{General design considerations}

There are no pre-spill data for hydrocarbons in sediments or for benthic invertebrate communities with which to compare our post-spill survey data in a BACI design (Stewart-Oaten 1996). As a result, we rely largely on post-spill comparisons of oiled versus reference sites to infer impacts. This After, Control-Impact design suffers in that making an inference with respect to impacts, based on differences between oiled and reference sites, rests on the assumption that hydrocarbon concentrations and benthic communities would have been similar in the absence of a spill (Wiens \& Parker 1995, Stewart-Oaten 1996). Obviously, this assumption is untestable, and we can not be certain that differences between oiled and reference sites were a result of the spill. The best that we can do is to point out when patterns that we observed are consistent with the hypothesis of spill related impacts, evaluate other sources of information (e.g. toxicity studies and prior oil spill studies), and make reasonable judgments based on the weight of evidence. A pattern in which oiled and reference sites differed is consistent with the hypothesis of an oil spill impact. A significant interaction between oiling category and year, with initial differences followed by convergence, is consistent with the hypothesis of initial impacts followed by recovery.

\section{Hydrocarbons in sediments}

The proportion of spilled oil from the 'Exxon Valdez' found in the shallow subtidal region ( 8 to $16 \%$ mainly at depths $<20 \mathrm{~m}$ ) was similar to that found subtidally from other major spills (i.e. 'Amoco Cadiz', 'Tsesis', 'Ixtoc', 'Argo Merchant') (O'Clair et al. 1996). Our hydrocarbon data, plus those of Boehm et al. (1995) and O'Clair et al. (1996), substantiate that the nearshore benthos was exposed to moderate levels of oiling and that TPAH concentrations were generally higher in shallow subtidal sediments near oiled shorelines than at ref- 
Table 9. Summary of randomization ANOVAs for the density of major taxonomic groups of benthic invertebrates. Covariates used in the analyses are listed. Also given are contrasts between oil and reference sites within years for those instances where there was a significant effect of oil category or a significant interaction between oil category and year

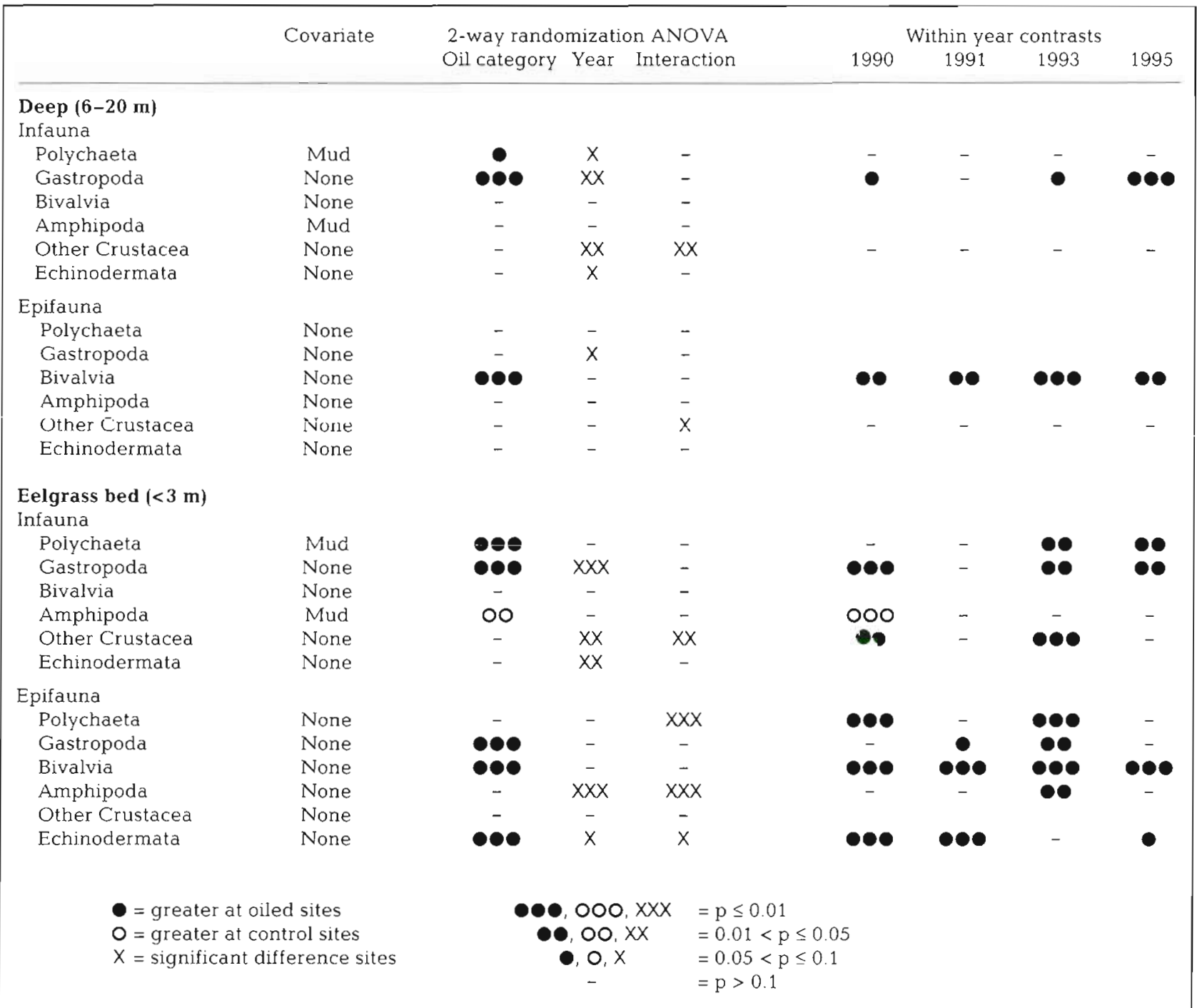

erence sites. However, relatively high concentrations of TPAHs were also observed at some reference sites and at least some of these samples had a signature matching 'Exxon Valdez' oil. This suggests that oil from the spill may have reached subtidal sediments even at sites relatively far removed from heavily oiled beaches and that inferences made with respect to effects of oil based on comparisons at oiled and reference sites are perhaps conservative estimates of injury. This is not unreasonable given that the mechanism by which oil reaches the subtidal is largely transported from the surface waters or oiled intertidal sediment on particulates by hydrodynamic forces. Larger differences in biological responses at oiled and reference sites might be expected, if reference sites had been totally free of oil from the spill.
It is likely that benthic populations were exposed to much higher concentrations of hydrocarbons than we measured in the sediments. Our samples were not collected until summer 1990, approx. 16 mo after the spill, and TPAH concentrations in subtidal sediments were generally higher in 1989 than in subsequent years, at least in the shallow $(<3 \mathrm{~m})$ subtidal $\left(\mathrm{O}^{\prime} \mathrm{Clair}\right.$ et al. 1996). There was considerable variability between sites and depths with respect to temporal trends, but at $3 \mathrm{~m}$ at the oiled sites sampled (Bay of Isles, Herring Bay, and Sleepy Bay), O'Clair et al. (1996) found an average $64 \%$ decline in TPAH concentrations between 1989 and 1990. At $6 \mathrm{~m}$ depths, TPAH concentrations decreased at 2 sites $(71$ and $78 \%$ at Bay of Isles and Herring Bay), but increased sharply at a third (300\% 
Table 10. Summary of randomization. ANOVAs for the density of dominant benthic invertebrate families at 6 to $20 \mathrm{~m}$. Covariates used in the analyses are listed. Also given are contrasts between oiled and reference sites within years for those instances where there was a significant effect of oil category or a significant interaction between oil category and year

\begin{tabular}{|c|c|c|c|c|c|c|c|c|}
\hline & \multirow[t]{2}{*}{ Covariate } & \multicolumn{3}{|c|}{ 2-way randomization ANOVA } & \multicolumn{4}{|c|}{ Within year contrasts } \\
\hline & & Oil category & Year Intera & action & 1990 & 1991 & 1993 & 1995 \\
\hline \multicolumn{9}{|l|}{ Infauna } \\
\hline \multicolumn{9}{|l|}{ Polychaeta } \\
\hline Ampharetidae & Mud & - & - & - & & & & \\
\hline Amphictenidae & None & - & $\mathrm{x}$ & - & & & & \\
\hline Capitellidae & Mud & - & - & - & & & & \\
\hline Lumbrineridae & None & 000 & - & - & - & - & - & 0 \\
\hline Maldanidae & Mud & 00 & - & - & $\bullet \bullet$ & $\bullet$ & - & - \\
\hline Nephtyidae & Mud & $\bullet$ & - & - & - & - & - & - \\
\hline Opheliidae & None & 00 & $x x x$ & - & 0 & - & 00 & - \\
\hline Orbiniidae & Mud & - & - & - & & & & \\
\hline Sabellidae & Mud & - & - & - & & & & \\
\hline Sigalionidae & None & - & - & - & & & & \\
\hline Spionidae & Mud & $\bullet$ & - & - & - & - & 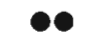 & - \\
\hline Syllidae & Mud & 00 & - & - & - & - & 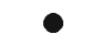 & - \\
\hline \multicolumn{9}{|l|}{ Gastropoda } \\
\hline Caecidae & None & $\bullet \bullet$ & - & - & $\bullet \bullet \bullet$ & $\bullet \bullet$ & - & 00 \\
\hline Olividae & Mud & - & $x$ & - & & & & \\
\hline Rissoidae & None & - & $x x x$ & - & & & & \\
\hline \multicolumn{9}{|l|}{ Bivalvia } \\
\hline Lucinidae & None & ০o & - & - & - & - & 0 & - \\
\hline Montacutidae & Mud & ০o & - & - & - & - & - & - \\
\hline Tellinidae & Mud & - & - & - & & & & \\
\hline Thyasiridae & None & 000 & - & - & - & $\infty 0$ & 000 & 000 \\
\hline \multicolumn{9}{|l|}{ Crustacea } \\
\hline Oedicerotidae & Mud & $\bullet$ & - & - & - & - & - & - \\
\hline Isaeidae & Mud & 0 & - & - & - & - & - & - \\
\hline Phoxocephalidae & Mud & 000 & $x X$ & $x$ & ০০ & 000 & - & - \\
\hline \multicolumn{9}{|l|}{ Echinodermata } \\
\hline Ophiuroidea & None & - & $x x$ & -- & & & & \\
\hline \multicolumn{9}{|l|}{ Epifauna } \\
\hline \multicolumn{9}{|l|}{ Polychaeta } \\
\hline Spirorbidae & None & - & - & - & & & & \\
\hline \multicolumn{9}{|l|}{ Bivalvia } \\
\hline Mytilidae & None & 00 & - & - & - & - & 00 & $\bullet$ \\
\hline \multicolumn{2}{|c|}{$\begin{array}{l}\mathbf{O}=\text { greater at oiled sites } \\
\mathbf{O}=\text { greater at control sites } \\
X=\text { significant difference sites }\end{array}$} & \multicolumn{2}{|c|}{$\begin{array}{l}000, x x x \\
0,00, x x \\
0, x \\
-\end{array}$} & $\begin{array}{l}=p \leq 0.01 \\
=0.01<p \leq 0.05 \\
=0.05<p \leq 0.1 \\
=p>0.1\end{array}$ & & & & \\
\hline
\end{tabular}

increase at Sleepy Bay). Also, sediments collected from sediment traps at Sleepy Bay in 1989 had TPAH concentrations as high as $28000 \mathrm{ng} \mathrm{g}^{-1}$ and were generally higher than in nearby sediments on the bottom (Short et al. 1996a), suggesting that exposure to oil in suspended sediments may have been higher than the exposure to deposited sediments.

Some of the hydrocarbon contamination observed was probably the result of spill-related activities as well as coal rather than spilled 'Exxon Valdez' oil (O'Clair et al. 1996, Short et al. 1999). At the peak of the cleanup and monitoring activities, over 1400 vessels were involved in the effort (Carpenter et al. 1991, Mearns 1996) and small accidental releases from these boats likely contributed to higher hydrocarbon concentrations. Naturally occurring TPAH in subtidal sediments is likely from coal deposits east of the Sound; contributions from oil seeps are negligible (Short et al. 1999). There is no way of knowing what proportion of the TPAHs observed were from the spill itself, from spill-related contamination, or from naturally occurring sources. However, the fact that 'Exxon Valdez' oil signatures and TPAH levels decreased substantially over time suggests that most of the contamination observed was spill or cleanup related. 
Table 11 Summary of randomization ANOVAs for the density of dominant benthic invertebrate familles within eelgrass beds $(<3 \mathrm{~m})$. Covariates used in the analyses are listed. Also given are contrasts between oiled and reference sites within years for those instances where there was a significant effect of oil category or a significant interaction between oil category and year

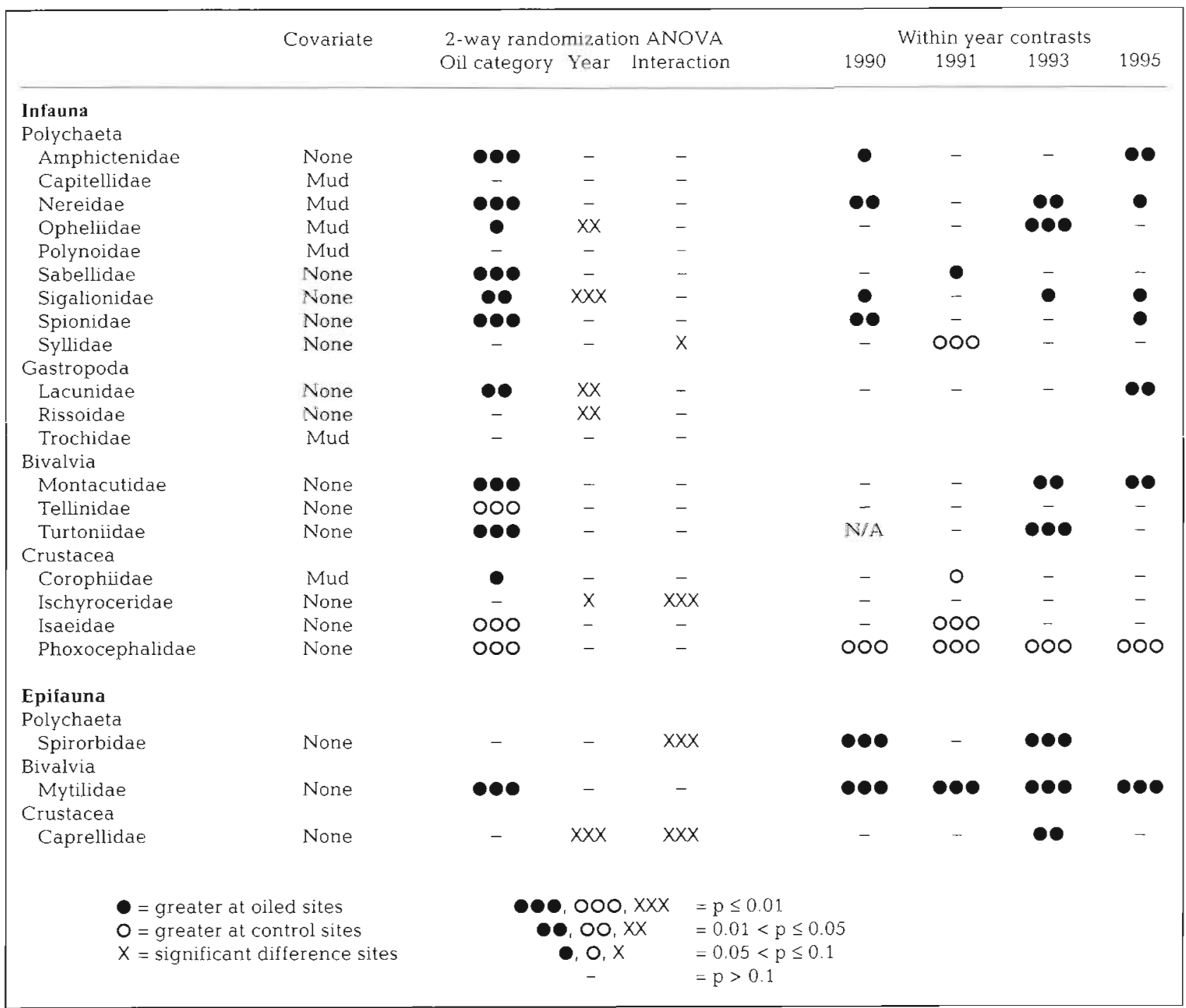

\section{Eifects on the benthos}

Similarity dendrograms and ordination analyses demonstrated that communities of infaunal and small epifaunal invertebrates were generally more similar at the same sites sampled in different years than at different sites sampled in the same year. In addition, selected pairs of sites were generally more similar to one another than sites from different pairs. These analyses suggest that, while all sites were within similar habitats in western Prince William Sound, there was considerable variability among sites, and that the subtle physical differences between sites were important in determining community structure. Analyses also suggest that selection of site pairs was generally successful in matching sites with similar characteristics. While factors other than oil were clearly the most important determinants of differences in community structure, the similarity dendrograms and ordination techniques indicate some effects of the spill. Bay of Isles in 1990 had the highest concentrations of TPAHs, and had a clearly different infaunal community at 6 to $20 \mathrm{~m}$, but not at $<3 \mathrm{~m}$, than other sites or years. Several other sites at $<3 \mathrm{~m}$ also appeared to be different in infauna in 1990 than in subsequent years, and these sites were those with exceptionally high concentrations of TPAH and chrysenes in 1990.

The patterns in community measures (total abundance, total biomass, diversity, and richness) were not indicative of a strong community-wide response to oil- 
Fig. 4. Mean density ( $\pm 1 \mathrm{SE}$ ) of Mytilidae (bivalves), Caecidae and Lacunidae (gastropods), and Spionidae, Syllidae, and Nereidae (polychaetes) that were representatives of families that were significantly more abundant at oiled sites. (-) Oiled, (0) reference. Two-way ANOVA results are summarized as p-values for comparisons of oil category (OC), year ( $\mathrm{Yr}$ ), and $\mathrm{OC}-\mathrm{Yr}$ interaction (Int)

ing. This is consistent with observations of Dauvin (1982) following the 'Amoco Cadiz' spill. In nearly $3 \mathrm{yr}$ after the spill he found increases in abundance of several benthic groups and declines in amphipods in a muddy-fine-sand community exposed to the 'Amoco Cadiz' oil spill, but no trends in diversity and evenness. In contrast, Sanders et al. (1980) found that there was a reduction in both diversity and total faunal abundance, as well as a clear reduction in the abundance of several major taxonomic groups following the 'Florida' spill (No. 2 fuel oil). The lack of a consistent response with respect to community parameters and higher order taxonomic groups following the 'Exxon Valdez' and 'Amoco Cadiz' spills probably reflects the different sensitivities of families within the particular faunal group, and the lack of exposure to high enough concentrations of oil to cause acute toxicity among all taxa.

Patterns among individual families portray a clearer picture of changes that presumably resulted from the spill. Two
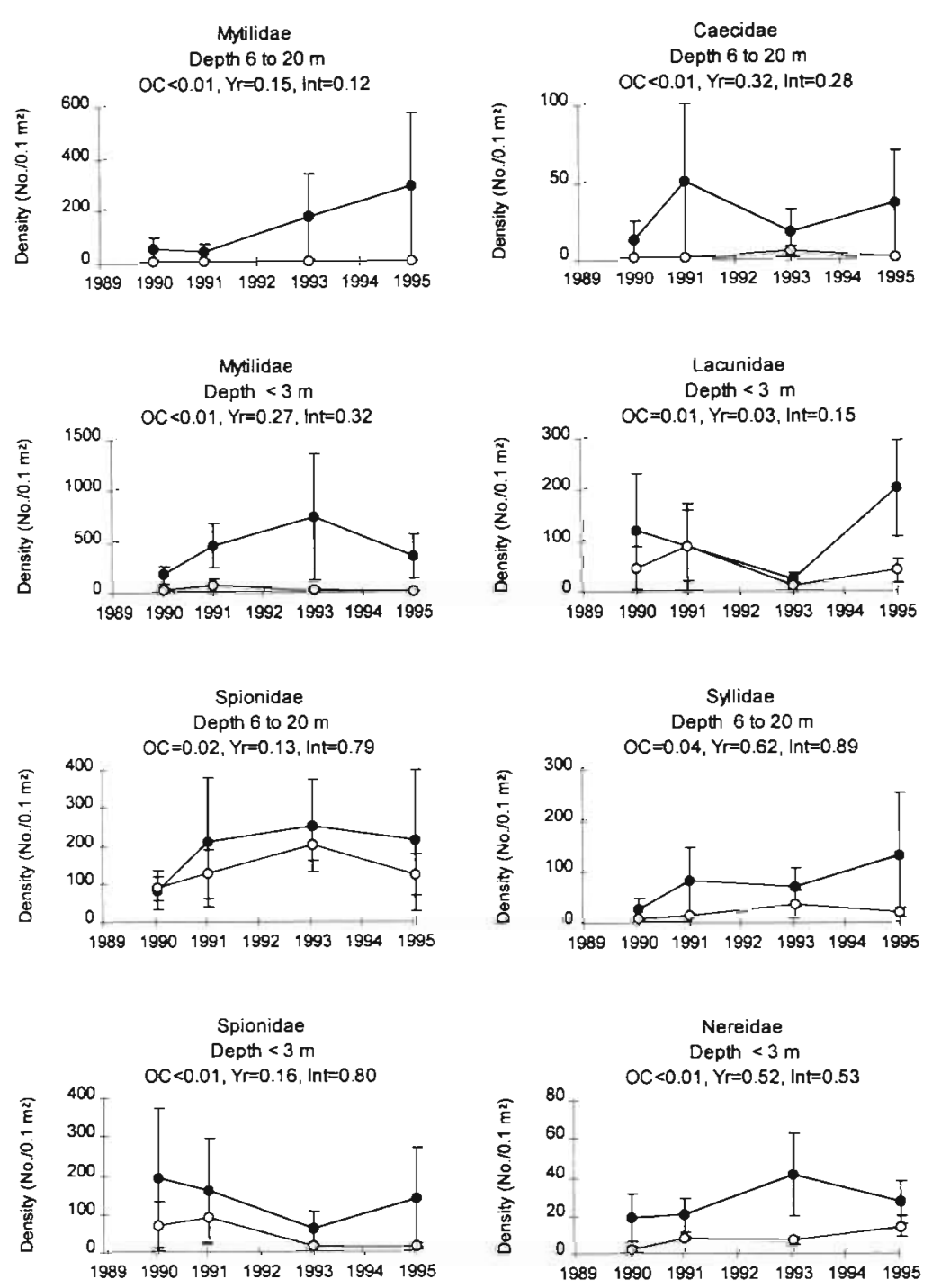
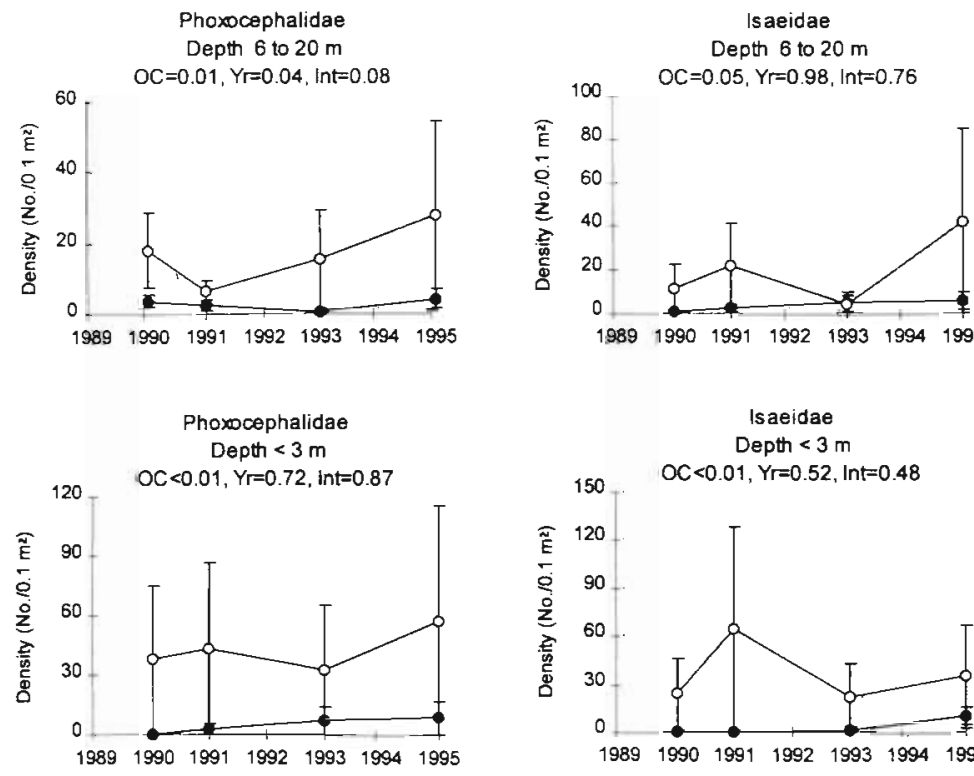

amphipod families, Isaeidae (primarily Photis and Protomedeia spp.) and Phoxocephalidae (mostly Phoxocephalus and Paraphoxus spp.), were consistently more abundant at reference than at oiled sites. Differences were greatest in 1990 through 1993, but persisted to some extent through 1995. This pattern is consistent with the hypothesis of an initial impact of the spill, followed by partial recovery. Two other amphipod families, Ischyroceridae and

Fig. 5. Mean density ( \pm 1 SE) of Phoxocephalidae and Isaeidae (amphipods) that were significantly more abundant at reference sites. ( O) Oiled; (0) reference. Two-way ANOVA results are summarized as p-values for comparisons of oil category $(O C)$, year (Yr), and OC-Yr interaction (Int) 

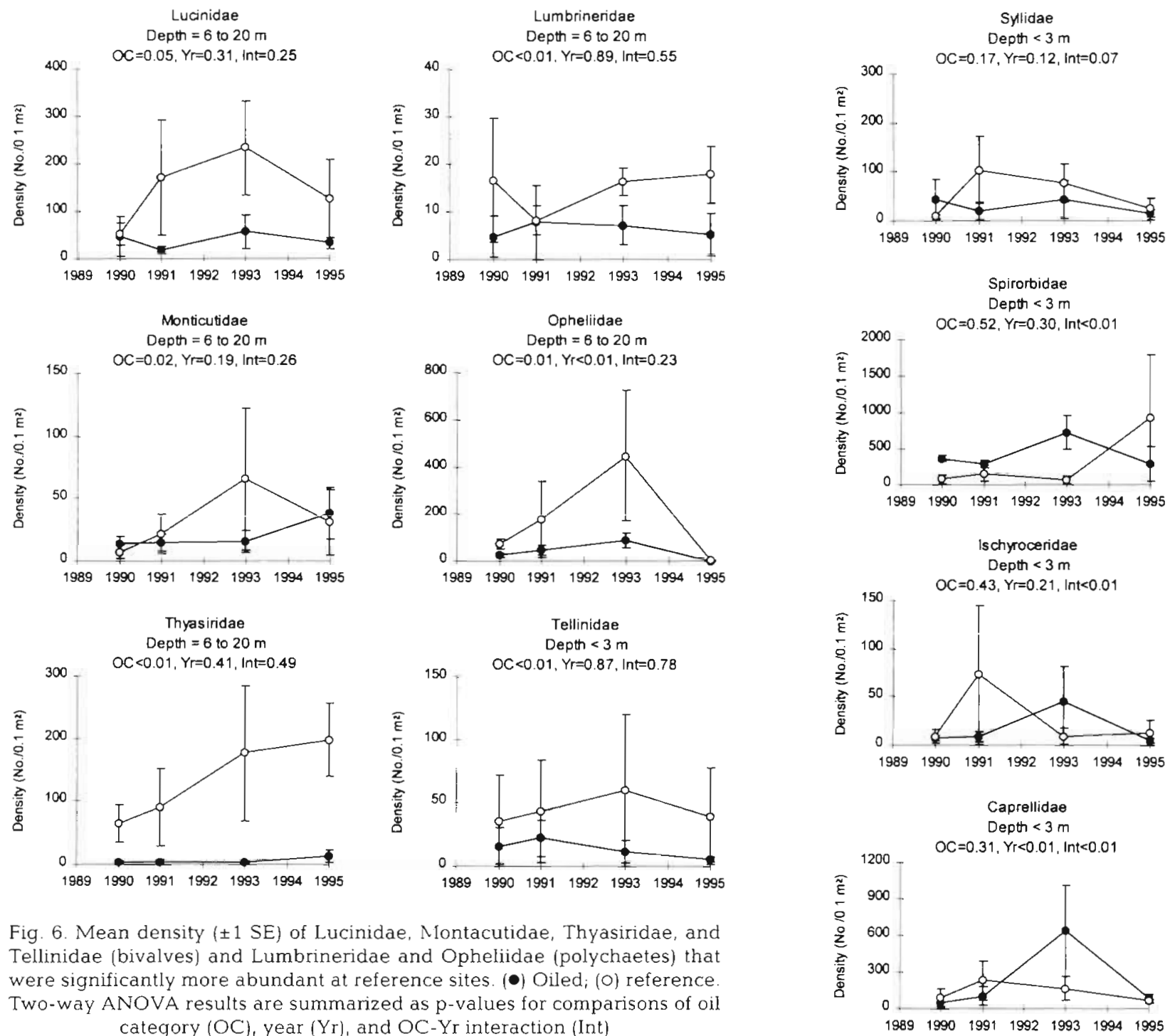

Fig. 6. Mean density ( \pm 1 SE) of Lucinidae, Montacutidae, Thyasiridae, and Tellinidae (bivalves) and Lumbrineridae and Opheliidae (polychaetes) that were significantly more abundant at reference sites. (•) Oiled; (0) reference. Two-way ANOVA results are summarized as p-values for comparisons of oil category $(\mathrm{OC})$, year (Yr), and OC-Yr interaction (Int)

Fig. 7. Mean density $( \pm 1$ SE) of Syllidae and Spirorbidae (polychaetes) and Ischyroceridae and Caprellidae (amphipods) for which there were significant interactions. (-) Oiled; (O) reference. Two-way ANOVA results are summarized as pvalues for comparisons of oil category $(O C)$, year $(Y r)$, and $\mathrm{OC}-\mathrm{Yr}$ interaction (Int) following the 'Amoco Cadiz' oil spill: 5 amphipod species almost totally disappeared from heavily oiled areas subsequent to the spill (Chassé 1978, den Hartog \& Jacobs 1980, Jacobs 1980, Dauvin \& Gentil 1990) and only showed partial recovery after 2 yr (Dauvin 1982). Similarly, massive mortality of amphipods were noted following other spills the 'Tsesis' spill: Linden et al. 1979, Kineman et al. 1980, Notini 1980, Elmgren et al. 1983; the 'Irini' spill: Notini 1978), and reductions in amphipods were noted at the most heavily oiled sites following the 'Braer' spill off the coast of Scotland (Kingston et al. 1997).

The relative scarcity of amphipods at oiled sites may have been the result of acute toxicity of oil, but evi- dence from toxicity tests is only mildly supportive of this hypothesis. Boehm et al. (1995) and Wolfe et al. (1996) tested for toxicity of sediments from the spill area using amphipods in standard laboratory toxicity tests in both 1990 and 1991. In 1990, Wolfe et al. (1996), using Ampelisca abdita, found that most intertidal sediment samples collected from oiled beaches caused significant toxicity, and mortalities were significantly greater in sediments from oiled than from reference sites. Similarly, Boehm et al. (1995), using the phoxocephalid Rhepoxynius abronius, found significant amphipod mortality in intertidal sediments from sev- 
eral oiled sites in both 1990 and 1991. There was less evidence for toxicity in subtidal sediments. Wolfe et al. (1996) noted that sediments from several subtidal sites, including all of our oiled sites (Sleepy Bay, Herring Bay, and Bay of Isles) were toxic in 1991. However, there was also significant toxicity in sediments from several reference sites, and there were no significant differences in amphipod mortality at oiled versus reference sites. Boehm et al. (1995) also found little evidence of toxicity in subtidal sediments, and also found no significant difference in toxicity between oiled and reference sites. Furthermore, reviews of contaminant effects on benthic communities (Long \& Morgan 1990 , Long 1992) suggest that toxicity occurs at TPAH concentrations of approx. $4000 \mathrm{ng} \mathrm{g}^{-1}$, higher than concentrations we observed in all but a few cases.

In spite of the lack of stronger evidence from these toxicity studies, we suspect that the lower amphipod abundance at oiled sites was at least in part due to acute toxicity to oil. Several lines of evidence suggest this. First, sediments collected from many (but not all) oiled sites in 1990 were toxic to amphipods (Wolfe et al. 1996). Second, sediments were not tested until nearly 16 mo after the spill. TPAH concentrations were generally higher in sediments in 1989 (O'Clair et al. 1996), and the oil in 1989 was less weathered and likely had a higher proportion of lighter fractions (Bence \& Burns 1995) that are generally more toxic (NRC 1985). Third, at least some sites in this study had TPAH concentrations up to $15000 \mathrm{ng} \mathrm{g}^{-1}$, perhaps high enough to cause mortality in amphipods according to some acute laboratory tests. For example, Lee et al. (1977) estimated that the amphipods Gammarus mucronatus and Ampithoe valida began to die when hydrocarbon concentrations in aqueous solutions of crude oil reached $2400 \mathrm{ng}$ $\mathrm{g}^{-1}$. Fourth, laboratory toxicity studies did not use the same species or physical conditions that occurred naturally in Prince William Sound, and may not reflect actual in situ toxicity levels. Finally, there is strong evidence for mortality to amphipods from other nearshore spills of comparable magnitude (Cabioch et al. 1980, den Hartog \& Jacobs 1980, Dauvin 1982, Elmgren et al. 1983, Kingston et al. 1997). It took more than 10 yr for the ampeliscid amphipod population to rebuild to pre'Amoco cadiz' spill densities (Dauvin 1998).

We also observed fewer individuals from 3 bivalve families at oiled sites: Thyasiridae and Montacutidae at 6 to $20 \mathrm{~m}$, and Tellinidae within the eelgrass bed, although not nearly as consistently as the amphipods. The principal genera within these families were the suspension- or deposit-feeding clams Thyasira, Mysella, and Macoma, respectively. Montacutidae showed a pattern consistent with initial impact followed by recovery. Other taxa were consistently more abundant at reference sites through 1995. It is unlikely that the differences in abundance were due solely to the acute toxicity of oil. Two representative species, Thyasira and Macoma, are known to be tolerant of hydrocarbon contamination and Thyasira has been shown to reach extremely high densities in grossly oil-contaminated conditions (Dando \& Southward 1986, Kingston et al. 1995). After the 'Tsesis' fuel oil spill, Elmgren et al. (1983) found that subtidal Macoma balthica (Tellinidae) were highly contaminated with oil (tissue concentrations of $2 \times 10^{6} \mathrm{ng} \mathrm{g}^{-1}$ ), but there were no indications of reductions in population abundance. Studies (in vitro and in situ) have shown that intertidal $M$. balthica were adversely affected by exposure to Prudhoe Bay crude oil in sediments, but only at much higher concentrations $\left(>5 \times 10^{5} \mathrm{ng} \mathrm{g}^{-1}\right.$ : Shaw et al. 1976, Taylor \& Karinen 1977, Stekoll et al. 1980) than we observed approx. 16 mo after the spill.

By far the more prevalent pattern was significantly greater abundance at oiled sites. Nine polychaete families were among those more abundant at oiled sites. Representatives of most of these, including amphictenids (Gray 1979), nereids (Boesch 1977, Gray 1979), spionids (Grassle \& Grassle 1974, Pearson \& Rosenberg 1978, Gray 1979), and syllids (Pearson \& Rosenberg 1978) have been shown to be tolerant of organic enrichment and additionally are classified as opportunists. More specifically, densities of both nereids (Kasymov \& Aliev 1973, Hyland et al. 1989) and spionids (Sanders et al. 1980, Dauvin 1998) have increased after oil spills elsewhere. Furthermore, Spies \& DesMarais (1983) showed that petroleum was utilized (via bacteria) by the maldanid Praxillella as a carbon source in a natural petroleum seep in the Santa Barbara Channel, CA, and suggested the petroleum was used in sufficient amounts to account for greater density of organisms observed in the seep than in a similar nonseep environment. Peterson et al. (1996) reviewed relevant studies from the literature on the dual response of toxicity and organic enrichment to soft-sediment benthic communities and noted a consistent pattern of depression of amphipods (as well as echinoderms) and an enhancement of polychaetes, mainly non-selective deposit feeders. Although oil likely was responsible for greater abundance of opportunists at oiled sites in the present study, caution must be used in attributing oil as the only cause. Numerous investigations have shown benthic opportunists to fluorish from organic enrichment of non-petroleum sources (e.g. Lizarraga-Partida 1974, Pearson \& Rosenberg 1978, Anderlini \& Wear 1992).

Some of the faunal increases in oiled habitats were attributable to the small epifaunal, suspension-feeding mytilid mussel, Musculus spp. Little information is available on the response of these organisms to oil, although considerable information is available on the 
response of other mytilids. Mytilus edulis and Modiolus demissus have been observed to increase respiration and decrease feeding and assimilation when exposed to crude oil concentrations of $1000 \mathrm{ng} \mathrm{g}^{-1}$ (Hyland \& Schneider 1976). However, $M$. edulis has generally been shown to be extremely hardy and resistant to pollutants, including oil (e.g. Lee et al. 1973, Farrington et al. 1982, Ganning et al. 1983, Viarengo \& Canesi 1991).

It is likely that many of the tolerant species were able to utilize increased carbon sources made available from the degradation of oil and shoreline application of chemical fertilizers to stimulate growth of hydrocarbon-utilizing bacteria (bioremediation). Significantly higher numbers of hydrocarbon-degrading microorganisms were found in intertidal and shallow $(<20 \mathrm{~m})$ subtidal sediments following the 'Exxon Valdez' spill, and declined between 1990 and 1993 (Braddock et al. $1995,1996)$. Increased microbial activity has also been observed following other oil spills (e.g. Colwell et al. 1978, Ward et al. 1980, Lizarraga-Partida et al. 1991). Spies (1987) found that benthic communities were stimulated through enhancement of microbial activity when hydrocarbon concentrations in sediment interstitial waters were in the range of 20 to $500 \mathrm{ng} \mathrm{g}^{-1}$. While these values are not directly comparable to our measurements of TPAHs in sediments, they suggest values we might expect based on our measured TPAH concentrations ( 45 to $15253 \mathrm{ng} \mathrm{g}^{-1}$ ) nearly 16 mo after the spill.

The increases in the abundance of some infauna, and especially the epifauna, may also have resulted from an indirect effect of oiling or cleanup on their predators. Significant reductions of both the crab Telmessus cheiragonus and the sea star Dermasterias imbricata were noted at oiled sites in 1990 (Dean et al. 1996b). These species feed on a variety of invertebrates including spirorbids and Musculus spp. (S. C. Jewett \& T. A. Dean pers. obs.). There was also a significant reduction in the population of sea otters in heavily oiled parts of the Sound (Ballachey et al. 1994). Otters eat a variety of benthic fauna and are considered keystone species that can have a profound effect on the structure of nearshore benthic systems (Kvitek et al. 1992a,b, Estes \& Duggins 1995). We did not see an increase in the abundance of most sea otter prey at oiled sites. However, the relatively small size of our sampling units was ill suited for estimating the abundance of larger clams such as Saxidomus giganteus and Protothaca staminea that are the principal foods of sea otters within the Sound (Calkins 1978, Doroff \& Bodkin 1994).

It is also possible that some of the increases in abundance at oiled sites were due to a reduction in competition, especially with amphipods. Elmgren et al. (1983) noted there was an unusually heavy recruitment of Macoma balthica in areas where subtidal amphipods were virtually eliminated following the 'Tsesis' spill, and they attributed the increases in Macoma to a reduction in competition with the amphipods. Similarly, van Bernem (1982) attributed a substantial increase in the abundance of oligochaetes on an oiled mudflat to a reduction of corophiid amphipod competitors.

Of all the families that showed a strong indication of possible enhancement due to oil, only 1, spirorbid polychaetes, showed a pattern of a reduction in the differences between oiled and reference sites over time that corresponded with a similar reduction in differences in TPAH concentrations. This suggests that differences in abundances at oiled and reference sites may have been unrelated to the impacts of oil, and instead may be attributed to inherent differences between sites. It is possible that those processes responsible for heavy oiling of some shorelines are also responsible for the concentration of planktonic larvae and food sources at those sites. Laur \& Haldorson (1996) suggested that oiling levels may be correlated with high food or larval abundances because sites with high rates of water movement were more likely to be encountered by the food and larvae, as well as oil, transported by currents. Dissolution rates of calcium sulfate cylinders at oiled and reference intertidal sites in Herring Bay were higher on the oiled site, indicative of greater water movement (R. C. Highsmith, University of Alaska, pers. comm.). This tends to support the hypothesis that some sites may have been heavily oiled and had higher densities of selected fauna simply because of greater water transport. However, such a hypothesis cannot easily explain why we observed lower abundances of some taxa at oiled sites, and why there were significant site by year interactions. Furthermore, this implies that these inherent differences between sites may have caused us to underestimate impacts. For example, reductions in phoxocephalid amphipods caused by the spill may have been even greater than indicated by oiled versus reference site comparisons.

Studies of the effects of oiling and cleanup conducted in the intertidal zone have indicated that cleanup activities, and especially the use of hot-water, high-pressure washing of oiled shorelines, was detrimental to intertidal communities, and often slowed recovery of intertidal populations (e.g. De Vogelaere \& Foster 1994, Driskell et al. 1996. Houghton et al. 1996, Lees et al. 1996). It is extremely difficult to make similar statements that discriminate among the effects of oiling, subsequent shoreline cleanup, or damage associated with cleanup and monitoring efforts on subtidal communities. While cleanup was often localized on a 
particular shoreline segment, the effects, including mobilization of oiled sediments and increased boat traffic, were often dispersed over a broader subtidal area, including reference sites. It seems likely that high-pressure washing of oiled shorelines was responsible for the redistribution of oil and oiled sediments that contributed to high oil concentrations in the subtidal zone (Mearns 1996).

Our experimental design focused on examining effects of the spill in and adjacent to eelgrass beds throughout the western Sound. Therefore, we used sampling sites (i.e. bays) as experimental units, and made statistical inferences to oiled versus reference sites and not to differences between individual sites However, distribution patterns of impacts among oiled sites are of interest because they suggest attributes that can be used to predict where the most severe impacts might occur and might suggest which kinds of sites should be given special consideration when responding to spills. Even within our small sample size and restricted sampling universe (eelgrass beds near moderately to heavily oiled shorelines), there appeared to be a high degree of variability between sites with respect to both exposure and impacts. Of the oiled sites we sampled, Bay of Isles had the highest TPAH concentrations and appeared to be the most severely impacted benthic community. This was most evident in ordination and clustering analysis which showed the community at Bay of Isles in 1990 to be quite different from the communities at other sites (both oiled and reference sites). Armstrong et al. (1995) also found that the tissues of bivalves from Bay of Isles had higher TPAH concentrations than those from elsewhere, and that flathead sole from this site had among the highest concentrations of fluorescent aromatic compounds (indicators of hydrocarbon exposure). Furthermore, Armstrong et al. (1995) found dead Tanner crabs at this and one other oiled site (Snug Harbor, western Prince William Sound) in Spring 1990, but not at other oiled or reference sites, and speculated that the deaths may have been caused by interactive effects of low salinity and oiling. The extent of shoreline oiling was no greater at Bay of Isles than at other oiled sites we sampled. However, Bay of Isles, and especially the extreme western portion of the Bay where we sampled, was particularly well protected from waves as evidenced by finer sediments observed there. Oil appears to be most persistent in these habitats (Page et al. 1995), and we suspect that the combination of heavy oiling and a low energy environment made this location particularly susceptible to adverse impacts of oil. This suggests that responders should focus on keeping oil from these protected habitats, and cleanup efforts should be conducted with an awareness of the special sensitivity of these environments.
The recovery process within benthic infaunal communities following oil spills generally follows a sequence of events which is as follows: (1) a toxic effect with considerable mortality; (2) an organically enriched period in which opportunistic taxa become extremely abundant; and (3) a period in which opportunists decrease in importance and fauna begin to return to conditions similar to adjacent unoiled areas and/or to a community characteristic of relatively undisturbed conditions (Pearson \& Rosenberg 1978, Glémarec \& Hussenot 1982, Ibanez \& Dauvin 1988, Spies et al. 1988). In 1990, 16 mo following the spill, the eelgrass community displayed patterns that were somewhat intermediate between the toxic phase and the enrichment phase. Since then, we have seen some patterns suggestive of recovery. For example, in 1995, TPAH concentrations were low (averaging $\leq 222 \mathrm{ng}$ $\mathrm{g}^{-1}$ ) and did not differ between oiled and reference sites. The total abundance and biomass of epifauna at $<3 \mathrm{~m}$ was significantly higher at oiled sites in 1990 and 1991, but not in 1995; and phoxocephalid amphipods at 6 to $20 \mathrm{~m}$ were more abundant at reference sites in 1990 and 1991, but not in subsequent years. However, for the most part, differences between oiled and reference sites persisted through 1995, and there was little indication of convergence. This is consistent with observations following the 'Florida' and 'Amoco Cadiz' spills which suggested that communities in muddyfine-sand sediments took between 1 (Sanders et al. 1980, Ibanez \& Dauvin 1988, Dauvin \& Gentil 1990) and 2 (Dauvin 1998) decades to fully recover.

Acknowledgements. We thank the more than 20 divers who helped collect the data, often under adverse conditions; those who assisted in the sorting and taxonomy of benthic invertebrates, including Kathy Omura and Max Hoberg; and those who helped with statistical issues, data management, and analyses, especially Lyman McDonald and Dennis Jung. Financial support was provided by the U.S. Forest Service, the Alaska Department of Fish \& Game, and the 'Exxon Valdez' Oil Spill Trustee Council. The findings and conclusions presented, however, are ours, and do not necessarily reflect the views or positions of the Trustee Council.

\section{LITERATURE CITED}

ADEC (Alaska Department of Environmental Conservation) (1989) Impact maps and summary reports of shoreline surveys of the Exxon Valdez oil spill site-Prince William Sound. Report to the Exxon Valdez Oil Spill Trustee Council. Anchorage, AK

Anderlini VC, Wear RG (1992) The effects of sewage and natural seasonal disturbances on benthic macrofaunal communities in Fitzroy Bay, Wellington, New Zealand. Mar Pollut Bull 24:21-26

Armstrong DA, Dinnel PA, Orensanz JM, Armstrong JL, McDonald TL, Cusimano RF, Nemeth RS, Landolt ML, Skalski JR, Lee RF, Huggett RJ (1995) Status of selected 
bottomfish and crustacean species in Prince William Sound following the Exxon Valdez oil spill. In: Wells PG, Butler JN, Hughes JS (eds) Exxon Valdez oil spill: fate and effects in Alaskan waters, ASTM STP 1219. American Society for Testing and Materials, Philadelphia, PA, p 485-547

Ballachey BE, Bodkin JL, DeGange AR (1994) An overview of sea otter studies in Prince William Sound. In: Loughlin TR (ed) Marine mammals and the Exxon Valdez. Academic Press, San Diego, p 47-59

Bassin NJ, Ichiye T (1977) Flocculation behavior of sediment and oil emulsions. J Sed Petrol 47:671-677

Bence AE, Burns WA (1995) Fingerprinting hydrocarbons in the biological resources of the Exxon Valdez spill area. In: Wells PG, Butler JN, Hughes JS (eds) Exxon Valdez oil spill: fate and effects in Alaskan waters, ASTM STP 1219. American Society for Testing and Materials, Philadelphia, PA, p 84-140

Boehm PD, Steinhauer MS, Green DR, Fowler B, Humphrey B, Fiest DL, Cretney WS (1987) Comparative fate of chemically dispersed and beached crude oil in subtidal sediments of the arctic nearshore. Arctic 40 (Suppl 1):133-148

Boehm PD, Page DS, Gilfillan ES, Stubblefield WA, Harner EJ (1995) Shoreline ecology program for Prince William Sound, Alaska, following the Exxon Valdez oil spill: part 2-chemistry and toxicology. In: Wells PG, Butler JN, Hughes JS (eds) Exxon Valdez oil spill: fate and effects in Alaskan waters, ASTM STP 1219. American Society for Testing and Materials, Philadelphia, PA, p 347-397

Boesch DF (1977) A new look at the zonation of benthos along the estuarine gradient. In: Coull BC (ed) Ecology of marine benthos. University of South Carolina Press, Columbia, p 245-266

Boström C. Bonsdorff E (1997) Community structure and spatial variation of benthic invertebrates associated with Zostera marina (L) in the northern Baltic Sea. J Sea Res $37: 153-166$

Braddock JF, Lindstrom JE, Brown EJ (1995) Distribution of hydrocarbon-degrading microorganisms in sediments from Prince William Sound, Alaska following the Exxon Valdez oil spill. Mar Pollut Bull 30:125-132

Braddock JF, Lindstrom JE, Yeager TR, Rasley BT, Brown EJ (1996) Patterns of microbial activity in oiled and unoiled sediments in Prince William Sound. In: Rice SD, Spies RB, Wolfe DA, Wright BA (eds) Proceedings of the Exxon Valdez oil spill symposium. Am Fish Soc Symp 18:94-108

Bray JR, Curtis JT (1957) An ordination of the upland forest communities of southern Wisconsin. Ecol Monogr 27:325-349

Cabioch L, Dauvin JC, Mora Bermudez J, Rodriguez Babio C (1980) Effects of the 'Amoco Cadiz' oil spill on the sublittoral benthos, north of Brittany. Helgol Meeresunters $33: 192-208$

Calkins, DG (1978) Feeding behavior and major prey species of the sea otter, Enhydra Jutris, in Montague Strait, Prince William. Sound, Alaska. Fish Bull 76:125-131

Carlson PR, Kvenvolden KA (1996) Tracking Exxon Valdez oil from beach to deep water sediments of Prince William Sound, Alaska. In: Rice SD, Spies RB, Wolfe DA, Wright $\mathrm{BA}$ (eds) Proceedings of the Exxon Valdez oil spill symposium. Am Fish Soc Symp 18:109-120

Carpenter AD, Dragnich RG, Smith MT (1991) Marine operations and logistics during the Exxon Valdez spill cleanup. In: Proceedings of the 1991 International oil spill conference: prevention, behavior, control, cleanup. American Petroleum Institute, Washington, DC, p 325-331

Chassé $C$ (1978) The ecological impact on and near shores by the Amoco Cadiz oil spill. Mar Pollut Bull 11:298-301

Clark RC Jr, MacLeod WD (1977) Inputs, transport mechanisms, and observed concentrations of petroleum in the marine environment. In: Malins DC (ed) Effects of petroleum on arctic and subarctic marine environments and organisms. Academic Press, New York, p 91-224

Clifford HT, Stephenson W (1975) An introduction to numerical classification. Academic Press, New York

Colwell RR, Mills AL, Walker JD, Garcia-Tello P, Campose PV (1978) Microbial ecology studies of the Metula spill in the Straits of Magellan. J Fish Res Board Can 35:573-580

Conover RJ (1971) Some relations between zooplankton and bunker $\mathrm{C}$ oil in Chedabucto Bay following the wreck of the tanker Arrow. J Fish Res Board Can 28:1327-1330

Cross WE, Martin CM, Thomson DH (1987) Effects of experimental releases of oil and dispersed oil on Arctic nearshore macrobenthos. 2. Epibenthos. Arctic 40 (Suppl 1): $201-210$

Dando PR, Southward AJ (1986) Chromatography in bivalve molluscs of the genus Thyasira. J Mar Biol Assoc UK 66: 915-929

Dauvin JC 11982) Impact of Amoco Cadiz oil spill on the muddy fine sand Ábra albã and Melinna palmata community from the Bay of Morlaix. Estuar Coast Shelf Sci 14: $517-531$

Dauvin JC (1998) The fine sand Abra alba community of the Bay of Morlaix twenty years after the Amoco Cadiz oil spill. Mar Pollut Bull 36:669-676

Dauvin JC, Gentil F (1990) Conditions of the peracarid populations of subtidal communities in northern Brittany ten years after the Amoco Cadiz oil spill. Mar Pollut Bull 21. $123-130$

Dean TA, Stekoll MS. Smith RO (1996a) Kelps and oil: the effects of the Exxon Valdez oil spill on subtidal algae. In: Rice SD, Spies RB, Wolfe DA, Wright BA (eds) Proceedings of the Exxon Valdez oil spill symposium. Am Fish Soc Symp 18:412-423

Dean TA, Jewett SC, Laur DR, Smith RO (1996b) Injury to epibenthic invertebrates resulting from the Exxon Valdez oil spill. In: Rice SD, Spies RB, Wolfe DA, Wright BA (eds) Proceedings of the Exxon Valdez oil spill symposium. Am Fish Soc Symp 18:424-439

Dean TA, Stekoll MS, Jewett SC, Smith RO, Hose JE (1998) Eelgrass (Zostera marina L.) in Prince William Sound, Alaska: effects of the Exxon Valdez oil spill. Mar Pollut Bull 36:201-210

den Hartog C, Jacobs RPWM (1980) Effects of the Amoco Cadiz oil spill on an eelgrass community at Roscoff (France) with special reference to the mobile benthic fauna. Helgol Meeresunters 33:182-191

De Vogelaere AP, Foster MS (1994) Damage and recovery in intertidal Fucus gardneri assemblages following the Exxon Valdez oil spill. Mar Ecol Prog Ser 106:263-271

Doroff AM, Bodkin JL (1994) Sea otter foraging behavior and hydrocarbon levels in prey. In: Loughlin T (ed) Marine mammals and the Exxon Valdez. Academic Press, San Diego, p 193-208

Driskell WB, Fukuyama AK, Houghton JP, Lees DC, Mearns AJ, Shigenaka G (1996) Recovery of Prince William Sound intertidal infauna from Exxon Valdez oiling and shoreline treatments, 1989 through 1992. In: Rice SD, Spies RB, Wolfe DA, Wright BA (eds) Proceedings of the Exxon Valdez oil spill symposium. Am Fish Soc Symp 18:362-378

Eberhardt LL, Thomas JM (1991) Designing environmental field studies. Ecol Monogr 61:53-73

Elmgren R, Frithsen JB (1982) The use of experimental ecosystems for evaluating the environmental impact of 
pollutants: a comparison of an oil spill in the Baltic Sea and 2 long-term, low-level oil addition experiments in mesocosms. In: Grice GD, Reeve MR (eds) Marine mesocosms biological and chemical research in experimental ecosystems. Springer Verlag, Inc, New York, p 153-165

Elmgren $R$, Hansson S, Larsson U, Sundelin B, Boehm PD (1983) The Tsesis oil spill: acute and long-term impact on the benthos. Mar Biol 73:51-65

Estes JA, Duggins DO (1995) Sea otters and kelp forests in Alaska: generality and variation in a community ecological paradigm. Ecol Monogr 65:75-100

Farrington JW, Davis AC, Frew NM, Rabin KS (1982) No 2 fuel oil compounds in Mytilus edulis: retention and release after an oil spill. Mar Biol 66:15-26

Feder HM, Blanchard A (1998) The deep benthos of Prince William Sound, Alaska, sixteen months after the Exxon Valdez oil spill. Mar Pollut Bull 36:118-130

Feder HM, Jewett SC (1987) The subtidal benthos. In: Hood DW, Zimmerman ST (eds) The Gulf of Alaska: physical environment and biological resources, Ocean Assessment Div., Alaska Office, U. S. Minerals Management Service Alaska OCS Region, MMS 86-0095, U.S. Govt. Printing Office, Washington, DC, p 347-396

Field JG, Clarke KR, Warwick RM (1982) A practical strategy for analyzing multi-species distribution patterns. Mar Ecol Prog Ser 8:37-52

Folk RL (1980) Petrology of sedimentary rocks. Hemphil Publishing Co, Austin, TX

Ganning B, Broman D, Lindblad C (1983) Uptake of petroleum hydrocarbons by the blue mussel (Mytilus edulis L.) after experimental oiling and high pressure, hot water shore cleaning. Mar Environ Res 10:245-254

Gilfillan ES, Page DS, Harner EJ, Boehm PD (1995) Shoreline ecology program for Prince William Sound, Alaska, following the Exxon Valdez oil spill: part 3-Biology. In: Wells PG, Butler JN, Hughes JS (eds) Exxon Valdez oil spill: fate and effects in Alaskan waters, ASTM STP 1219 American Society for Testing and Materials, Philadelphia, PA, p 398-443

Glémarec M, Hussenot E (1982) A three-year ecological survey in Benoit and Wrac'h Abers following the Amoco Cadiz oil spill. Neth J Sea Res 16:483-490

Grassle JF, Grassle JP (1974) Opportunistic life histories and genetic systems in marine benthic polychaetes. J Mar Res $32: 253-284$

Grassle JF, Elmgren R, Grassle JP (1981) Response of benthic communities in MERL experimental ecosystems to low level, chronic additions of No. 2 fuel oil. Mar Environ Res $4: 279-297$

Gray JS (1979) Pollution-induced changes in populations. Phil Trans Royal Soc Lond Bull 286:545-561

Grebmeier JM, Feder HM, McRoy CP (1989) Pelagic-benthic coupling on the shelf of the northern Bering and Chukchi Seas. II. Benthic community structure. Mar Ecol Prog Ser 51:253-268

Green RH (1979) Sampling design and statistical methods for environmental biologists. John Wiley \& Sons, New York

Gundlach ER, Boehm PD, Marchand M, Atlas RM, Ward DM, Wolfe DA (1983) The fate of the Amoco Cadiz oil spill. Science 221:122-131

Highsmith RC, Rucker TL, Stekoll MS, Saupe SM, Lindeberg MR, Jenne RN, Erickson WP (1996) Impact of the Exxon Valdez oil spill on intertidal biota. In: Rice SD, Spies RB, Wolfe DA, Wright BA (eds) Proceedings of the Exxon Valdez oil spill symposium. Am Fish Soc Symp 18:212-237

Houghton JP, Lees DC, Driskell WB, Lindstrom SC, Mearns AJ (1996) Recovery of Prince William Sound intertidal epibiota from Exxon Valdez oiling and shoreline treatments, 1989 through 1992. In: Rice SD, Spies RB, Wolfe DA, Wright BA (eds) Proceedings of the Exxon Valdez oil spill symposium. Am Fish Soc Symp 18:379-411

Hyland JL, Schneider ED (1976) Petroleum hydrocarbons and their effects on marine organisms, populations, communities and ecosystems In: Sources, effects and sinks of hydrocarbons in the aquatic environment. Symposium proceedings. American Institute of Biological Sciences. American University, Washington, DC, p 464-506

Hyland JL, Kennedy J, Campbell J, Williams S, Boehm P. Uhler A, Steinhauer W (1989) Environmental effects of the Pac Baroness oil and copper spill. In: Proceedings of the 1989 oil spill conference. API, EPA, and USCG (sponsors), San Antonio, TX, p 413-419

Ibanez F, Dauvin JC (1988) Long-term changes (1977-1987) in a muddy fine sand Abra alba-Melinna palmata community from the Western English Channel: multivariate timeseries analysis. Mar Ecol Prog Ser 49:65-81

Jacobs RPWM (1980) Effects of the Amoco Cadiz oil spill on the seagrass community at Roscoff with special reference to the benthic infauna. Mar Ecol Prog Ser 2:207-212

Jewett SC, Dean TA, Laur DR (1996) The effects of the Exxon Valdez oil spill on benthic invertebrates in an oxygendeficient embayment in Prince William Sound, Alaska. In: Rice SD, Spies RB, Wolfe DA, Wright BA (eds) Proceedings of the Exxon Valdez oil spill symposium. Am Fish Soc Symp 18:440-447

Kasymov AG, Aliev AD (1973) Experimental study of the effect of oil on some representatives of benthos in the Caspian Sea. Water Air Soil Pollut 2:235-245

Kelso DD, Kendziorek M (1991) Alaska's response to the Exxon Valdez oil spill. Environ Sci Technol 25:16-23

Kineman JJ, Elmgren R, Hansson S (1980) The Tsesis oil spill. U.S. Dept of Commerce, Office of Marine Pollution Assessment, National Oceanic and Atmospheric Administration, Boulder, $\mathrm{CO}$

Kingston PF, Dixon IMT, Hamilton S, Moore DC (1995) The impact of the Braer oil spill on the macrobenthic infauna of the sediments off the Shetland Islands. Mar Pollut Bull $30(7): 445-459$

Kingston PF, Dixon IMT, Hamilton S, Moore CG, Moore DC (1997) Studies on the response of intertidal and subtidal marine benthic communities to the Braer oil spill. In: Davies JM, Topping G (eds) The impact of an oil spill in turbulent waters: the Braer. The Stationery Office, Edinburgh, p 209-233

Kvitek RG, Oliver JS (1992a) Influence of sea otters on softbottom prey communities in southeast Alaska. Mar Ecol Prog Ser 82:103-113

Kvitek RG, Oliver JS (1992b) Changes in Alaska soft-bottom prey communities along a gradient in sea otter predation. Ecology 73:413-428

Laur D, Haldorson L (1996) Coastal habitat studies: the effect of the Exxon Valdez oil spill on shallow subtidal fishes in Prince William Sound. In: Rice SD, Spies RB, Wolfe DA, Wright BA (eds) Proceedings of the Exxon Valdez oil spill symposium. Am Fish Soc Symp 18:659-670

Lee RF, Sauerheber R, Benson A. (1973) Petroleum hydrocarbons: uptake and discharge by the marine mussel Mytilus edulis. Science 177:344-346

Lee WY, Welch MF, Nicol JAC (1977) Survival of two species of amphipods in aqueous extracts of petroleum oils. Mar Pollut Bull 8:92-94

Lees DC, Houghton JP, Driskell WB (1996) Short-term effects of several types of shoreline treatment on rocky intertidal biota in Prince William Sound. In: Rice SD, Spies RB, Wolfe 
DA, Wright BA (eds) Proceedings of the Exxon Valdez oil spill symposium. Am Fish Soc Symp 18:329-348

Linden O, Elmgren R, Boehm PD (1979) The Tsesisoil spillits impact on the coastal ecosystem of the Baltic Sea. Ambio 8:244-253

Lizarraga-Partida ML (1974) Organic pollution in Ensenada Bay, Mexico. Mar Pollut Bull 5:109-112

Lizarraga-Partida $M L$, Izquierdo-Vicuna FB, Wong-Chang I (1991) Marine bacteria on the Campeche Bank oil field Mar Pollut Bull 22:401-405

Long ER (1992) Ranges in chemical concentrations in sediments associated with adverse biological effects. Mar Pollut Bull 24:38-45

Long ER, Morgan LG (1990) The potential for biological effects of sediment-sorbed contaminants tested in the National Status and Trends Program. NOAA Tech Memo NOS OMA 52, NOAA, Seattle

Maki AW (1991) The Exxon Valdez oil spill: initial environmental impact assessment. Environ Sci Technol 25:24-29

Manly B (1991) Randomization and Monte Carlo methods in biology. Chapman and Hall, London

Mapstone BD (1995) Scaleable decision rules for environmental impact studies: effect size, Type I and Type II errors. Ecol Appl 5:401-410

McConnaughey T, McRoy CP $(1979){ }^{13} \mathrm{C}$ label identifies eelgrass (Zostera marina) carbon in an Alaskan estuarine food weh. Mar Biol 53:26.3-269

McRoy CP (1970) Standing stocks and other features of eelgrass (Zostera marina) populations on the coast of Alaska J Fish Res Board Can 27:1811-1821

Mearns AJ (1996) Exxon Valdez shoreline treatment and operations: implications for response, assessment, monitoring, and research. In: Rice SD, Spies RB, Wolfe DA, Wright BA (eds) Proceedings of the Exxon Valdez oil spill symposium. Am Fish Soc Symp 18:309-328

Meyers PA, Quinn JG (1973) Association of hydrocarbons and mineral particles in saline solution. Nature 244:23-24

NRC (National Research Council) (1985) Oil in the sea: inputs fates, and effects. National Academy Press, Washington DC

Notini M (1978) Long-term effects of an oil spill on Fucus macrofauna in a small Baltic bay. J Fish Res Board Can 35:745-753

Notini M (1980) Impact of oil on the littoral ecosystemeffects on Fucus macrofauna. In: Kineman JJ, EImgren R, Hansson S (eds) The Tsesis oil spill. National Oceanic and Atmospheric Administration, Boulder, CO, p 129-145

O'Clair CE, Short JW, Rice SD (1996) Contamination of intertidal and subtidal sediments by oil from the Exxon Valdez in Prince William Sound. In: Rice SD, Spies RB, Wolfe DA, Wright BA (eds) Proceedings of the Exxon Valdez oil spill symposium. Am Fish Soc Symp 18:61--93

Olsgard F, Gray JS (1995) A comprehensive analysis of the effects of offshore oil and gas exploration and production on the benthic communities of the Norwegian continental shelf. Mar Ecol Prog Ser 122:277-306

Owens EH, Harper JR, Robson W, Boehm PD (1987) Fate and persistence of crude oil stranded on a sheltered beach. Arctic 40 (Suppl 1):109-123

Page DS, Boehm PD, Douglas GS, Bence AE (1995) Identification of hydrocarbon sources in the benthic sediments of Prince William Sound and the Gulf of Alaska following the Exxon Valdez oil spill. In: Wells PG, Butler JN, Hughes JS (eds) Exxon Valdez oil spill: fate and effects in Alaskan waters, ASTM STP 1219. American Society for Testing and Materials, Philadelphia, PA, p 41-83

Pearson TH, Rosenberg R (1978) Macrobenthic succession in relation to organic enrichment and pollution of the marine environment. Oceanogr Mar Biol Annu Rev 16:229-311

Peterson $\mathrm{CH}$, Kennicutt MC II, Green RH, Montagna $P$, Harper DE Jr, Powell EN, Roscigno PF (1996) Ecological consequences of environmental perturbations associated with offshore hydrocarbon production: a perspective on long-term exposures in the Gulf of Mexico. Can J Fish Aquat Sci 53:2637-2654

Phillips RC (1984) The ecology of eelgrass meadows in the Pacific Northwest: a community profile. U.S. Fish \& Wildlife Service OBS $84 / 24$

Rhoads DC (1974) Organism-sediment relations on the muddy sea floor. Oceanogr Mar Biol Annu Rev 12:263-300

Sanders HL, Grassle JF, Hampson GR, Morse LS, GarnerPrice $S$, Jones CC (1980) Anatomy of an oil spill: long-term effects from the grounding of the barge Florida off WestFalmouth, Massachusetts. J Mar Res 38:265-380

Shannon CE, Weaver W (1963) The mathematical theory of communication. University of Illinois Press, Urbana

Shaw DG, Paul AJ, Cheek LM, Feder HM (1976) Macoma balthica: an indicator of nil nollution. Mar Pollut Bull $7(2): 29-31$

Short JW, Sale DM, Gibeaut JC (1996a) Nearshore transport of hydrocarbons and sediments after the Exxon Valdez oil spill. In: Rice SD, Spies RB, Wolfe DA, Wright BA (eds) Proceedings of the Exxon Valdez oil spill symposium. Am Fish Soc Symp 18:40-60

Short JW, Jackson TJ, Larsen ML, Wade TL (1996b) Analytical methods used for the analysis of hydrocarbons in crude oil, tissues, sediments, and seawater collected for the Natural Resources Damage Assessment of the Exxon Valdez Oil Spill. In: Rice SD, Spies RB, Wolfe DA, Wright BA (eds) Proceedings of the Exxon Valdez oil spill symposium. Am Fish Soc Symp 18:140-148

Short JW, Kvenvolden KA, Carlson PR, Hostettler FD, Rosenbauer RJ, Wright BA (1999) Natural hydrocarbon background in benthic sediments of Prince William Sound, Alaska: oil vs coal. Environ Sci Technol 33:34-42

Spies RB (1987) The biological effects of petroleum hydrocarbons in the sea: assessments from the field and microcosms. Chapter 9. In: Boesch DF, Rabalais NN (eds) Long-term environmental effects of offshore oil and gas development. Elsevier Applied Science, London, p 411-467

Spies RB, DesMarais DJ (1983) Natural isotope study of trophic enrichment of marine benthic communities by petroleum seepage. Mar Biol 73:67-71

Spies RB, Hardin DD, Toal JP (1988) Organic enrichment or toxicity: a comparison of the effects of kelp and crude oil in sediments on the colonization and growth of benthic infauna. J Exp Mar Biol Ecol 124:261-282

Spies RB, Rice SD. Wolfe DA, Wright BA (1996) The effects of the Exxon Valdez Oil Spill on the Alaskan coastal environment. In: Rice SD, Spies RB, Wolfe DA, Wright BA (eds) Proceedings of the Exxon Valdez oil spill symposium. Am Fish Soc Symp 18:1-16

Stekoll MS, Clement LE, Shaw DG (1980) Sublethal effects of chronic exposure on the intertidal clam Macoma balthica Mar Biol 57:51-60

Stekoll MS, Deysher L, Highsmith RC, Saupe SM, Guo Z, Erickson WP, McDonald L, Srickland D (1996) Coastal habitat injury assessment: intertidal communities and the Exxon Valdez oil spill. In: Rice SD, Spies RB, Wolfe DA, Wright BA (eds) Proceedings of the Exxon Valdez oil spill symposium. Am Fish Soc Symp 18:177-192

Stewart-Oaten A (1996) Problems in the analysis of environ- 
mental monitoring data. In: Schmitt RJ, Osenberg CW (eds) Detecting ecological impacts. Academic Press, San Diego, p 109-131

Taylor TL, Karinen JF (1977) Response of the clam, Macoma balthica (Linnaeus), exposed to Prudhoe Bay crude oil as unmixed oil, water-soluble fraction, and oil-contaminated sediment in the laboratory. In: Wolfe DA (ed) Fate and effects of petroleum hydrocarbons in the marine ecosystems and organisms. Pergamon Press, New York, p 229-237

Thayer JK, Phillips RC (1977) Importance of eelgrass beds in Puget Sound. Mar Fish Rev 36:27-39

van Bernem KH (1982) Effects of experimental crude oil contamination on abundance, mortality and resettlement of representative mudflat organisms in the mesohaline area of the Elbe Estuary. Neth J Sea Res 16:538-546

van Tamelen PG, Stekoll MS, Deysher L (1997) Recovery processes of the brown alga Fucus gardneri following the 'Exxon Valdez' oil spill: settlement and recruitment. Mar Ecol Prog Ser 160:265-277

Venkatesan MI (1988) Occurrence and possible sources of

Editorial responsibility: Charles Peterson (Contributing Editor), Morehead City, North Carolina, USA perylene in marine sediments - a review. Mar Chem 25:1-27

Viarengo A, Canesi L (1991) Mussels as biological indicators of pollution. Aquaculture 94:225-243

Ward DM, Atlas RM, Boehm PD, Calder JA (1980) Microbial biodegradation and chemical evolution of oil from the Amoco spill. Ambio 9:277-283

Warwick RM, Clarke KR (1993) Comparing the severity of disturbance: a meta-analysis of marine macrobenthic community data. Mar Ecol Prog Ser 92:221-231

Wiens JA, Parker KR (1995) Analyzing the effects of accidental environmental impacts: approaches and assumptions. Ecol Appl 5:1069-1083

Wolfe DA, and 11 co-authors (1994) The fate of oil spilled from the Exxon Valdez. Environ Sci Technol 28:561A-568A

Wolfe DA, Krahn MM, Casillas E, Sol S, Thomas TA, Lunz J, Scott KJ (1996) Toxicity of intertidal and subtidal sediments in contaminated by the Exxon Valdez oil spill. In: Rice SD, Spies RB, Wolfe DA, Wright BA (eds) Proceedings of the Exxon Valdez oil spill symposium. Am Fish Soc Symp 18:121-139

Submitted: February 18, 1998; Accepted: December 14, 1998 Proofs received from author(s): July 30, 1999 